\title{
Systems Evaluation of Subsonic Hybrid-Electric Propulsion Concepts for NASA N+3 Goals and Conceptual Aircraft Sizing
}

\author{
S. S. Jagtap \\ The Daniel Guggenheim School of Aerospace Engineering, \\ Georgia Institute of Technology, Atlanta, Georgia, 30332. \\ *Email: swapniljagtap111@gmail.com
}

\begin{abstract}
The air-travel demand is anticipated to grow in future and therefore the worldwide airtraffic is forecast to increase significantly. This growth in demand further increases the concerns pertaining to environmental and human health, which results in stringent aviation policies. Emission regulations have been set for the aviation sector to reduce its climate change impacts, and these support the efforts to meet the goals of the UN's Paris treaty on climate change. The aviation sector is exploring sustainable and improved technologies to become more energy and cost efficient. Along these lines, NASA has developed the concept of ' $\mathrm{N}+\mathrm{i}$ ' goals to decrease fuel consumption, noise, and landing and take-off (LTO) oxides of nitrogen $\left(\mathrm{NO}_{\mathrm{x}}\right)$ emissions, and to enhance aircraft performance. The ' $\mathrm{N}+3$ ' represents three technology generations into the future, where ' $\mathrm{N}$ ' represents the current aircraft generation, with a forecasted technology readiness level 4-6, in year 2025 timeframe which will enable year 2035 service-entry. To meet NASA's $\mathrm{N}+3$ goals, significant improvements must be made in the air transportation system, airframe, mission design, and propulsion systems. A pivotal element to achieve these goals, is the propulsion system. This is because the role of propulsion system can be crucial in reducing emissions, noise, and fuel burn. This work evaluates the $\mathrm{N}+3$ concepts in detail, based on the systems engineering approaches and selects the best of those concepts. A detailed analysis is presented for phase one of such a project using Georgia Institute of Technology's Integrated Product-Process Development (IPPD) method. This work finds that the NASA N3-X turbo-electric distributed propulsion (TeDP) is the best concept for meeting the NASA N+3 goals, based on the systems engineering approach.
\end{abstract}

Keywords: Systems engineering and theory; system of systems engineering; engineering management; TQM; aerospace components; aerospace engineering; aerospace systems engineering; complex systems engineering.

\section{NOMENCLATURE}

NASA national aeronautics and space administration

LTO landing and take off

IPCC intergovernmental panel on climate change

IATA international air transport association

FAA federal aviation administration

CAEP committee on aviation environmental protection

ATC air traffic control

ASTM American society for testing and materials

SPK synthetic paraffin kerosene 


$\begin{array}{ll}\text { FT } & \text { Fischer-Tropsch } \\ \text { HRJ } & \text { hydro-processed renewable jet fuel } \\ \text { HEFA } & \text { hydro-processed esters and fatty acids } \\ \text { HFS-SIP } & \text { hydro-processed fermented sugars to synthetic iso-paraffins } \\ \text { ATJ } & \text { alcohol to jet fuel } \\ \mathrm{CO}_{2} & \text { carbon dioxide } \\ \mathrm{CO} & \text { carbon monoxide } \\ \mathrm{NO}_{\mathrm{x}} & \text { nitrogen oxides } \\ \mathrm{SO}_{\mathrm{x}} & \text { sulfur oxides } \\ \text { TeDP } & \text { turbo-electric distributed propulsion } \\ \text { SELECT } & \text { silent efficient low-emissions commercial transport } \\ \text { SUGAR } & \text { Subsonic Ultra Green Aircraft Research } \\ \text { IPPD } & \text { integrated product process development } \\ \text { QFD } & \text { quality function deployment } \\ \text { OEC } & \text { overall evaluation criterion } \\ \text { TOPSIS } & \text { technique for order preference by similarity to ideal solution }\end{array}$

\section{INTRODUCTION}

In future, both passenger and freight air-travel demand is anticipated to grow and the worldwide air-traffic is forecasted to increase significantly until at least 2036 [1]. Boeing forecasts yearly average global growth rate of $4.2 \%$ for freight air-traffic and $4.7 \%$ for passenger air-traffic, during the year 2017-2036 [2]. The aviation sector provided services to about 62 million tonnes of freight and 4 billion passengers, in the year 2016. While providing these services, it contributed to $3.6 \%$ of the global gross domestic product [3]. The directly associated aviation sector's share of the anthropogenic carbon dioxide $\left(\mathrm{CO}_{2}\right)$ emissions worldwide is $2 \%$ [3],[4]. The aviation sector reached 895 million tonnes of $\mathrm{CO}_{2}$ and consumed 94 billion gallons of fuel globally, in the year 2018 [5]. The aircraft exhaust comprises of $\mathrm{CO}_{2}$, carbon monoxide $(\mathrm{CO})$, nitrogen oxides $\left(\mathrm{NO}_{\mathrm{x}}\right)$, water vapour, sulfur oxides $\left(\mathrm{SO}_{\mathrm{x}}\right)$, unburned hydrocarbons, traces of nitrogen compounds and hydroxyl family, a small number of soot particles, and normal atmospheric oxygen and nitrogen [6]. Considering non- $\mathrm{CO}_{2}$ emissions and their effects, the intergovernmental panel on climate change (IPCC) forecasts that aviation contributes to about $3 \%$ of the total anthropogenic climate change impact. The IPCC estimates that aviation's total share is predicted to increase to 5\% by the year 2050 (accounting a worst-case scenario of $15 \%$ of human emissions) [6].

The above-mentioned growth in air-travel demand further increases the concerns pertaining to environmental and human health [7]. These result in stringent aviation policies. In future, there are emission regulations set for the aviation sector for reducing its climate change impact, and these support the efforts to meet the goals of the UN's Paris treaty on climate change. Additionally, while doing so it has to ensure the necessary quantity of fuel supplies are met [7]. Therefore, the aviation sector is exploring sustainable pathways to become more energy and cost-efficient [7]. These sustainable efforts are explored in detail in the next section. The International air transport association (IATA) has established three targets and a four-pillar strategy to meet these goals [8], which are in-line with the goals UN's Paris treaty on climate change. The three goals are:

i. An average improvement in fuel efficiency of $1.5 \%$ per year from year 2009 to 2020 [8]; 
ii. A reduction in net aviation $\mathrm{CO}_{2}$ emissions of $50 \%$ by year 2050 , relative to year 2005 levels [8]; and

iii. A cap on net aviation $\mathrm{CO}_{2}$ emissions from year 2020 (carbon-neutral growth) [8]; The four-pillar strategy includes:

i. Improved technology, including the deployment of sustainable low-carbon fuels [8];

ii. Infrastructure improvements, including modernized air traffic management systems [8];

iii. More efficient aircraft operations [8]; and

iv. A single global market-based measure, to fill the remaining emissions gap [8].

\section{FUTURE AVIATION TECHNOLOGIES}

In order to fulfil performance, noise and emissions goals, NASA introduced N+3 goals to motivate new aircraft technologies and concepts, targeted to enter the market in the 2030-2035 timeframe [9],[10]. ' $\mathrm{N}+\mathrm{i}$ ' nomenclature is used to define aircraft generations sequentially, where $\mathrm{N}$ represents the present generation and ' $\mathrm{i}$ ' indicates a particular generation after $\mathrm{N}$ [9],[10]. The $\mathrm{N}+\mathrm{i}$ aircraft technology will largely be possible because of improvements in airframe structure, aerodynamics, and propulsion-energy. These include the use of blended/hybrid wing body aircraft, an unconventional airframe architecture, with better performance in terms of the aircraft structure, weight reduction and aerodynamics, compared to present-day aircraft [11]. In terms of propulsion, there are advanced technologies like ultra-high bypass ratio turbofan engines, hybrid-electric and full-electric concepts [12]. The future aircraft engines will have cleaner/lowemissions and improved combustors [13], [14]. Such combustors will control combustion instabilities, a phenomenon observed in present-day aircraft combustors [13], [14]. These next generation of improved combustors further increase the safety aspect of an aircraft [13], [14].

Alternative fuels viz. bio-jet fuels are planned to be used in aircraft [15]. Bio-jet fuels from certain feedstocks and pathways provide a significant reduction in life-cycle greenhouse gas (GHG) emissions, compared to the conventional jet fuel [7], [16], [17], [18]. Presently, the American society for testing and materials (ASTM) has approved certain bio-jet fuel pathways which can be used in aircraft as 'drop-in' fuels. These are Fischer-Tropsch (FT) SPK (FT-SPK) with maximum 50\% blend [17]; Hydro-processed lipids/hydro-processed renewable jet fuel or Hydro-processed esters \& fatty acids (HRJ/HEFA-SPK) with maximum 50\% blend [7]; Biochem sugars or hydro-processed fermented sugars to synthetic iso-paraffins (HFS-SIP) with maximum 10\% blend [16]; Syngas FT with aromatic alkylation (FT-SPK/A) with maximum 50\% blend; and alcohol to jet (ATJ-SPK) with maximum 30\% blend [18]; where the blending is done with the conventional jet fuel [19].

To improve the efficiency of aircraft, heat recovery in thrust-powered aircraft [20], [21]; and shaft-powered aircraft [22], [23], [24], is being pursued for a long time, especially in the past two decades, using organic Rankine cycle. With such recovery systems, there is always a balancing act between efficiency improvement and weight addition [22], [23], [24].

The N+3 generation establishes rigorous environmental and performance goals which encourage many groundbreaking concepts compared to the former ones. The criteria of $\mathrm{N}+3$ generation includes a $71 \mathrm{~dB}$ cumulative reduction in noise of aircraft under noise regulation of FAA (federal aviation administration) Stage 4, reducing the landing 
and take-off (LTO) $\mathrm{NO}_{\mathrm{x}}$ emissions by $75 \%$ in reference to CAEP (committee on aviation environmental protection) 6 , and reducing the fuel burn of the mission by $70 \%$ in reference to present-day technology [9],[10]. The air transportation has environmental impacts since aircraft engines consume fuel and release noise, greenhouse gases, particulates and heat which results in climate change and cause damage to human health, natural resources and ecosystem quality.

The studies [25]-[27] explore the pure form of hybrid-electric propulsion, and the study [28] investigates the full-electric aircraft. The study by Voskuijl et al. [27] considers a regional jet (70 passenger turbo-prop) with a range of $1528 \mathrm{~km}$ using $1000 \mathrm{Wh} / \mathrm{kg}$ batteries, where $34 \%$ electric shaft power requires $28 \%$ less mission fuel at the expense of a larger aircraft in terms of weight and wing area. The study by Voskuijl et al. provides maximum fuel-saving benefits of all the mentioned studies on hybrid-electric aircraft. However, they do not consider the impacts of turbo-prop noise. The study by Schäfer et al. [28] on all-electric aircraft with battery packs of $800 \mathrm{Wh} / \mathrm{kg}$, enables a range up to 600 nautical miles $(1,111 \mathrm{~km})$ for 150 passengers, mitigate airport area $\mathrm{NO}_{\mathrm{x}}$ emissions by $40 \%$, and reduce fuel use and direct $\mathrm{CO}_{2}$ emissions by $15 \%$. Of the studies so far, hybridelectric propulsion in the pure form has benefits in fuel savings, but it cannot meet the NASA N+3 goals. Therefore, a combination of many advanced technologies should be used to meet these goals, which includes the benefits of blended/hybrid wing body aircraft (as discussed previously). This technology combination is discussed in further sections of this work, especially for the NASA N3-X Turboelectric Distributed Propulsion (TeDP) concept.

There is an increased affinity of the industry towards systems engineering for solving complex systems problems because of the significant benefits it offers. This include better product or process in the hands of the customer; reduced design lead time; reduced design changes; reduced errors in production or delivery; improved reliability; reduced introduction costs; reduced warranty claims; reduced through-life costs; better traceability of decision making; more ability to manage and afford change; management of risk; and improved organisational learning [29]. There are several studies which address the N+3 hybrid-electric propulsion concepts [30]-[37], and some of these studies address and focus on individual concepts and their performance. These include studies by Chambers et al. [32] on Massachusetts Institute of Technology's (MIT) double-bubble concept, Armstrong et al. [33] on NASA N3-X Turboelectric distributed propulsion (TeDP), Bradley et al. [34] on Boeing subsonic ultra-green aircraft research (SUGAR) Volt; and Bruner et al. [35] on Northrop Grumman silent efficient low-emissions commercial transport (SELECT). However, studies [30]-[37] neither conduct a detailed comparative assessment between different hybrid-electric propulsion concepts nor conduct any system engineering analysis of these concepts. The study by Ashcraft et al. [9] reviews all the hybrid-electric propulsion concepts (and readers are advised to explore it for knowing the details of these concepts) and it is the closest of all studies to the scope of this work. The study by Ashcraft et al. only use quality function deployment (QFD) for a systems-level assessment, and the QFD is limited to only propulsion technologies. The study by Ashcraft et al. motivates a systems-level analysis at the propulsion and airframe level. A detailed analysis is demanded which implements the systems engineering approach considering the limitations and shortcomings of the previous studies, and this work addresses the same. The demand for detailed systems-level analysis is the motivation for this work. 


\section{METHODOLOGY}

The objective of this work is to perform a detailed systems-engineering study on existing $\mathrm{N}+3$ concepts, assessing the usefulness of the advanced technologies and concepts with the present-day aircraft as the baseline, after which, the best of those concepts is selected. The scope of this work is restricted to phase 1. The first phase consists of integrated product-process development (IPPD). The QFD is implemented which results to give a collection of feasible technologies within the scope of this work. The goal of this work is to conceive a large commercial subsonic aircraft to meet the requirements comprising of: cruise Mach $0.72-0.8 ; 300$ seat class; service-entry by 2035; hybrid-electric propulsion system; N+3 goals as described above; comply to FAA regulations. The discussion and results of this work will be helpful for designers and decision-makers for technology design-development and policymaking. The above is the significance of this work.

In phase 1, the IPPD methodology developed by the Georgia Institute of Technology [38] is used to select the best alternative to meet the defined goals for aircraft using hybrid-electric propulsion. The next section i.e. results and discussion address and discuss the aspects and steps involved in the IPPD methodology with results, in the context of this work. The steps in the IPPD methodology consists of:

i. Establish a need:

This step comprises defining the customer's needs, perform requirements analysis, and defining the operational and functional architectures. The operational and functional architecture include the mission objectives, and systems operational and functional background;

ii. Define the problem:

This step includes QFD analysis.

iii. Establish a value:

Evaluation is done using feasibility criteria and constraints, and overall evaluation criterion (OEC);

iv. Generate alternatives:

This step comprises generating feasible alternatives and its evaluation, using the morphological matrix; and

v. Decision making:

Based on the above four steps, a decision is taken using the 'technique for order preference by similarity to ideal solution' (TOPSIS) and Pugh matrix.

\section{RESULTS AND DISCUSSION}

\section{Establish a Need}

\section{Operational architecture}

The operational architecture comprises of the mission and the interactions between various systems for the successful completion of one duty cycle of an aircraft [39]. Figure 1 gives the operational architecture of this duty cycle. The air traffic control (ATC) instructs the taxi to unload (from previous duty cycle). The ATC is not in active communication with the aircraft during the unloading process as well as the loading process for the next duty cycle. With the beginning of the new cycle, the ATC instructs the pilot of the aircraft to taxi, takeoff, climb and cruise by giving necessary clearances at required times in one duty cycle. When the duty cycle is to end, the ATC instructs the 
pilot to descend and land. If there is a space management issue on the runway, the ATC instructs for necessary loiter, and then make necessary arrangements for landing. After the aircraft lands the same operations are performed as described above.

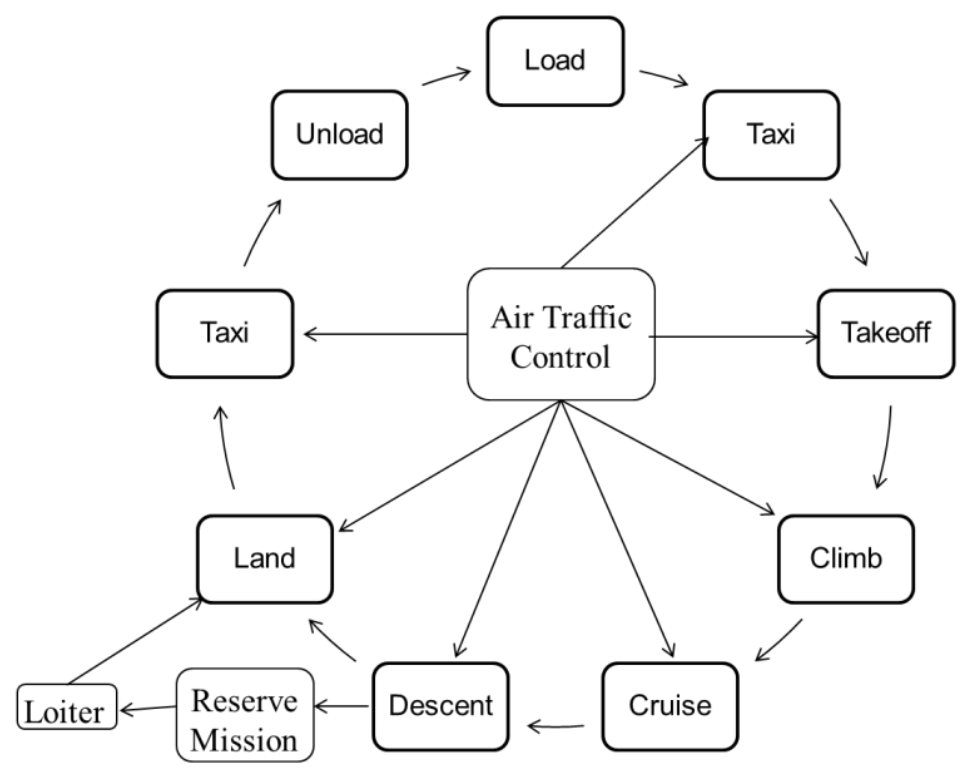

Figure 1. Operational architecture of duty-cycle.

\section{Functional architecture}

It recognises and organises the assigned performance and operational requirements [39]. As indicated in Figure 2, the functional requirements of an aircraft are divided into three main components like airframe, propulsion and flight controls. These main components are further broken down to subcomponents.

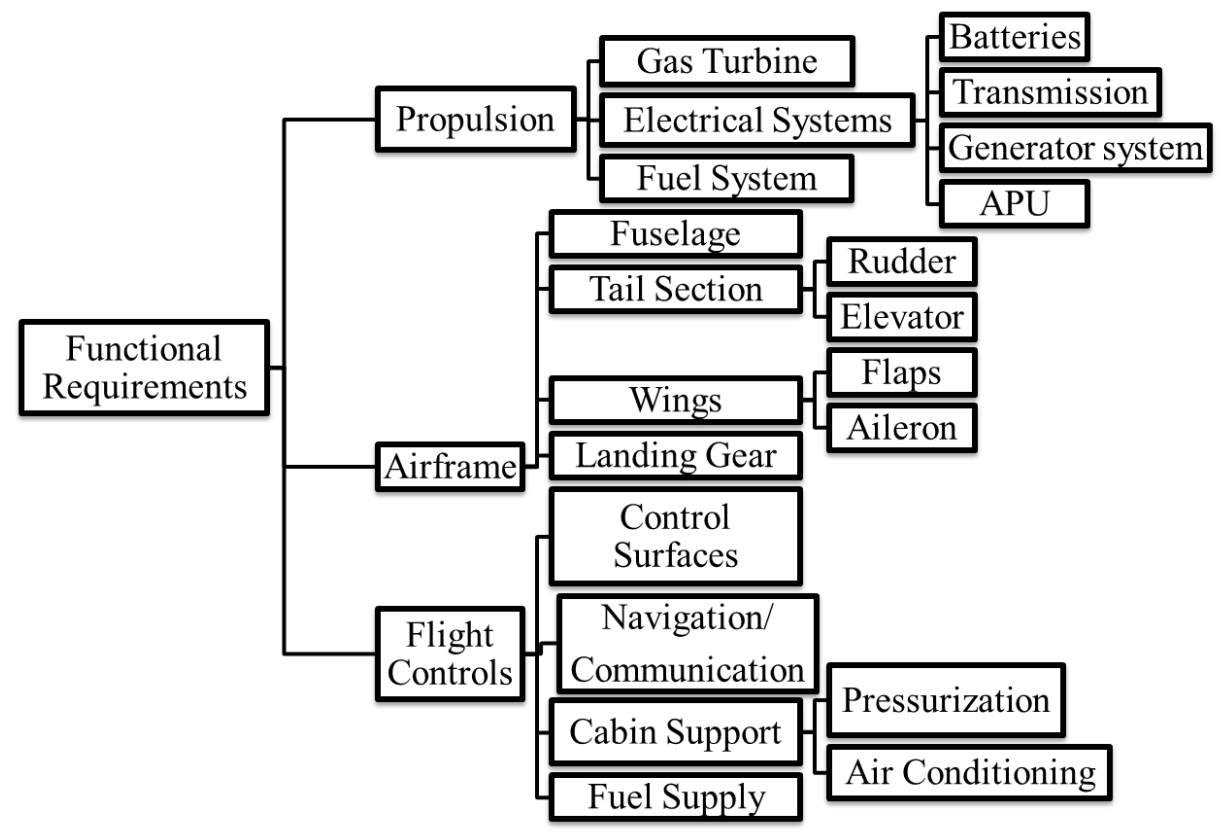

Figure 2. Functional architecture of an aircraft. 


\section{Information flow}

Figure 3 demonstrates the information flow (among sub-systems) in case of an aircraft for successful completion of the mission. The flight control system feeds information to the fuel system based on the operating conditions like take off, cruise or landing. Necessary fuel is thus supplied to the gas turbine functioning. The gas turbine along with generating thrust for propulsion, powers the generator after which the power is supplied via a transmission system to the electric motor. Based on the operating conditions the battery performs accordingly either storing or shelling out energy. The electric motor powers the turbine systems which generate required thrust for propulsion. The transmission system also powers the flight control systems through the electrical systems. The flight control system feeds information to the transmission system based on the operating conditions where it regulates the power it receives from the generator. This way all subsystems interact and perform the work in a duty cycle.

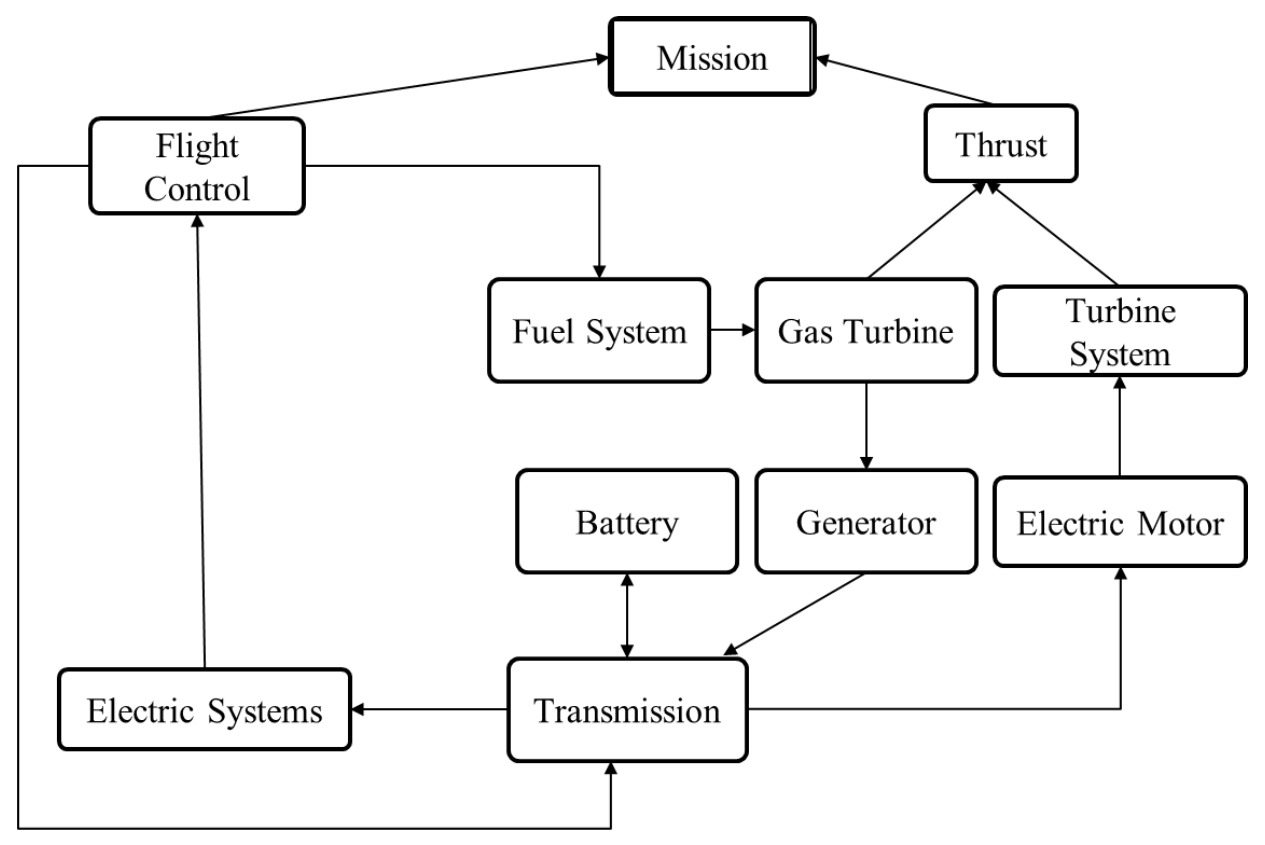

Figure 3. Information flow diagram and sub-systems interaction during a mission.

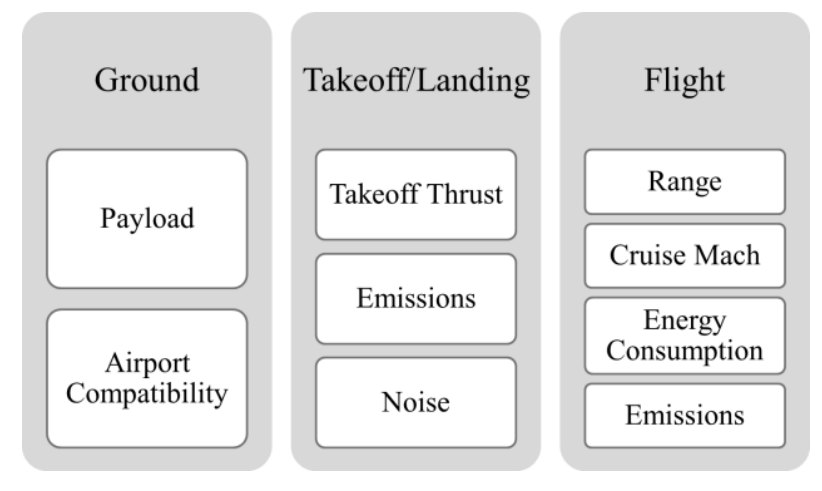

Figure 4. Performance requirement over a flight mission. 


\section{Performance requirements}

For a commercial aircraft, the main customer requirement for $\mathrm{N}+3$ technology goals and the associated other requirements are found. The requirements are chosen in such a way that the aircraft suffices the payload considerations and from architecture point of view it also needs to be compatible with the existing airports. Figure 4 illustrates the performance requirements over a flight mission. The aircraft needs to generate required amount of thrust at takeoff and throughout the entire mission profile, and it should be constrained by N+3 goals. Range and cruise Mach both should be enough to compete with the baseline or existing market product.

\section{Affinity diagram}

For organising ideas and information systematically, a tool called 'affinity diagram' is used [40], [41]. The affinity diagram is shown in Figure 5, where characteristics/requirements ('Whats') of an aircraft are classified in four main categories.



Figure 5. Affinity diagram showing the four characteristics of an aircraft.

\section{Tree diagram}

Typically, a tree diagram is a classification of 'Whats' (requirements) and 'Hows' (method to perform the requirements) [41], [42]. The 'Whats' are the customer requirements and the other associated requirements. The 'Whats' are taken from the affinity diagram in Figure 5. The 'Hows' are the medium by which the challenges in 'Whats' can be addressed. The tree diagram specific to this work is shown in Figure 6, which includes the requirements and the methods/means by which these requirements can be fulfilled. 


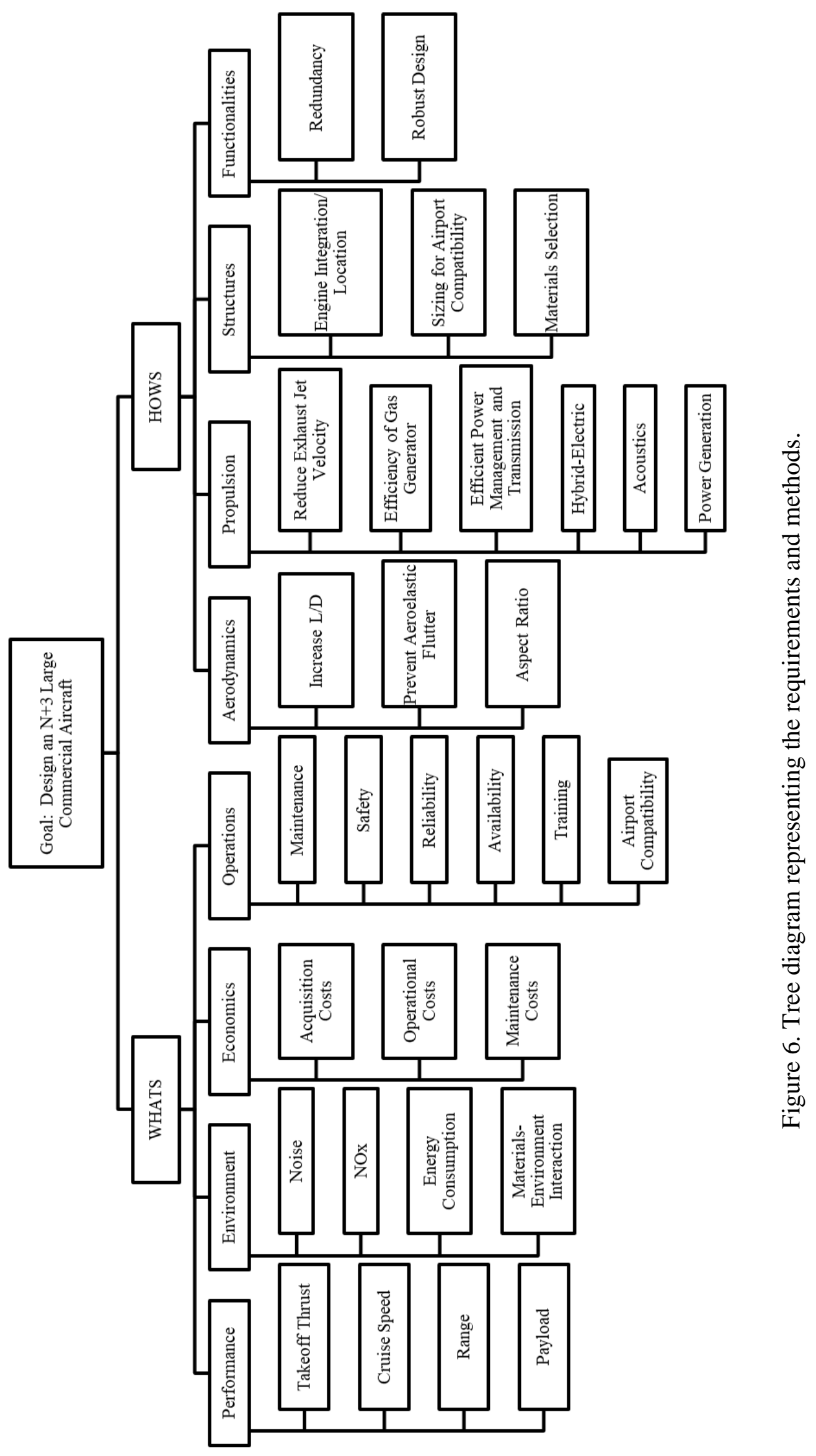




\section{Interrelationship digraph}

It is a tool, which is implemented to find cause and effect relationships among the study parameters [41]-[43], as shown in Figure 7. Arrows leaving an element indicate that element is a driver, while arrows into an element indicate an outcome. Based on the results presented in Figure 7, the most important parameters are found to be propulsion architecture, airframe architecture, energy consumption, operational costs, and payload. In consistency with the primary objectives of this work, propulsion architecture is identified as the main driver and operational costs identified as the main outcome.

\section{Prioritisation matrix}

A prioritisation matrix is used to allocate weights to various system requirements [41][44]. The relative importance of issues is then ranked by analyzing each issue with respect to others. Theprioritisation matrix provided in Table 1 shows that the most important issues to the customer are safety, energy consumption, and payload. Safety is of utmost importance to airline companies for a number of legal and social reasons. Thus, purchasing an aircraft that is unsafe and does not meet regulations, is not an option. Energy consumption is also a high priority to the customer because fuel costs contribute directly to overall operational costs, which is identified as a main outcome from the interrelationship digraph. Finally, commercial airlines are concerned with maximum payload when purchasing new aircraft as it relates to profit margin. Ultimately, commercial airline companies are seeking to maximize revenues, minimise costs, and avoid any issues that could lead to a loss in business or legal disputes.

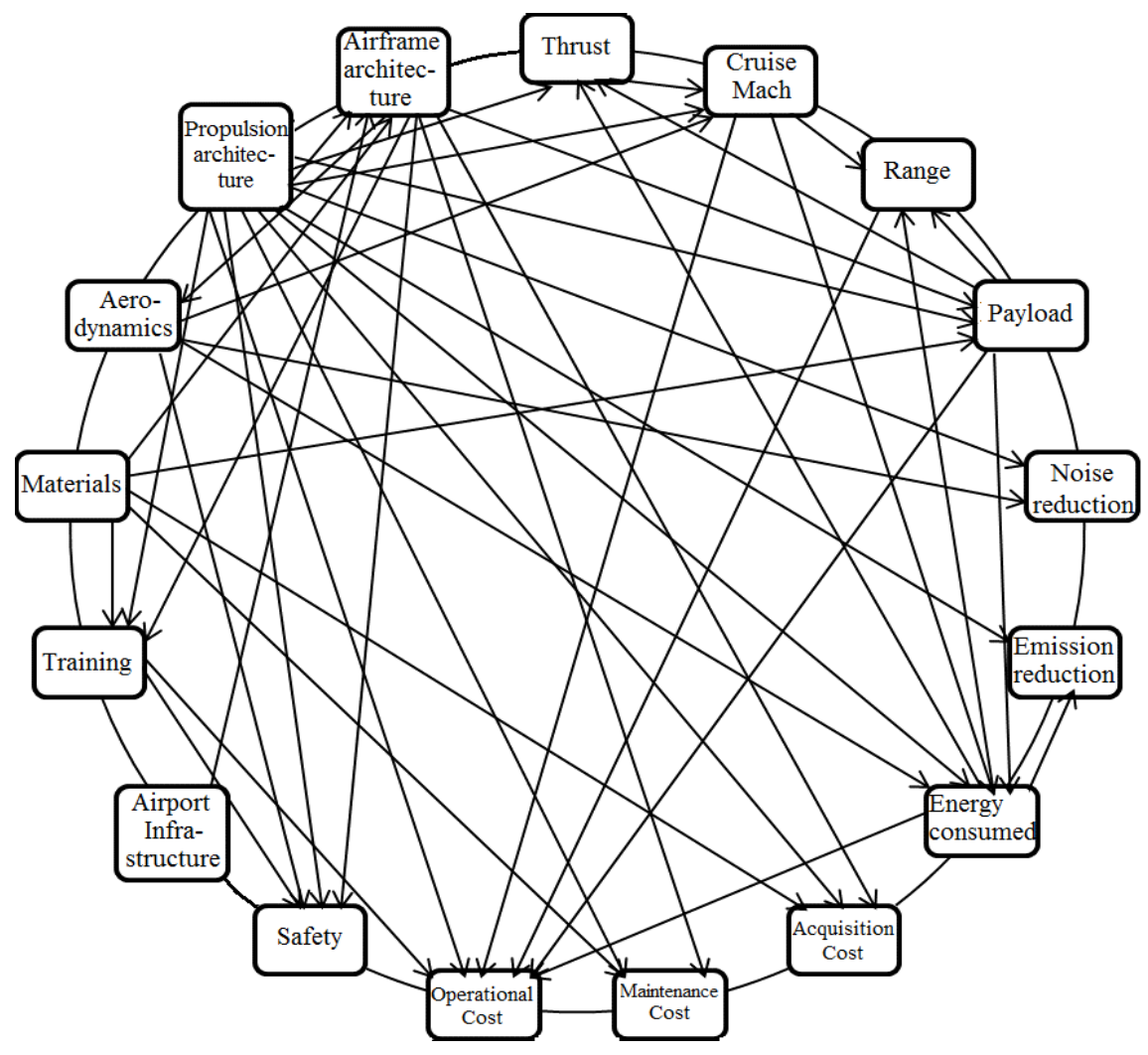

Figure 7. Interrelationship digraph showing the cause-effect relation between study parameters. 
Table 1. Prioritisation Matrix with weight allocation to various system requirements.

\begin{tabular}{|c|c|c|c|c|c|c|c|c|c|c|c|c|c|c|c|c|c|c|}
\hline Criteria & $\stackrel{\overrightarrow{\underline{a}}}{\vec{Z}}$ & 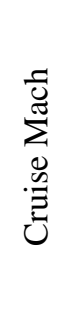 &  & $\frac{\vec{J}}{\stackrel{\Xi}{\pi}}$ & $\begin{array}{l}0 \\
\frac{.0}{0} \\
\dot{z}\end{array}$ & 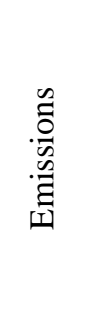 & 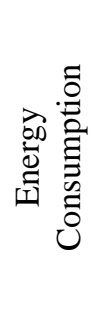 & U & $\stackrel{U}{\Sigma}$ & ర & 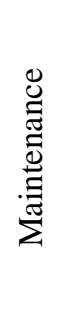 & 告 & 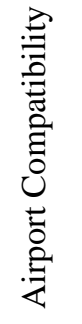 & $\frac{\vec{D}}{\sqrt[D]{n}}$ & 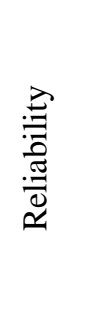 & $\overline{\underline{\Sigma}}$ & 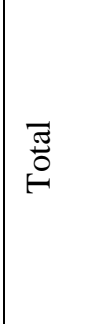 & $\%$ \\
\hline Thrust & & 1 & 0.2 & 0.2 & 0.2 & 1 & 02 & 5 & 5 & 5 & 5 & 5 & 1 & 0.20 & 0.2 & 5 & 34.2 & 6 \\
\hline ach & 1 & & 0.2 & 2 & 0.2 & 0.2 & 0 & 5 & 5 & 0.2 & 5 & 5 & 1 & 0.2 & 1 & 12 & 25.3 & 5 \\
\hline in: & 5 & 5 & & 1 & 1 & 0.2 & 1 & 5 & 5 & 1 & 5 & 5 & 1 & 0.2 & 1 & 13 & 37.4 & 7 \\
\hline d & 5 & 5 & 1 & & 1 & 0.2 & 0.2 & 10 & 10 & 1 & 5 & 10 & 1 & 0.2 & 1 & 55 & 55.6 & 10 \\
\hline oise & 5 & 5 & 1 & 1 & & 1 & 0.2 & 5 & 5 & 1 & 5 & 5 & 5 & 0.2 & 1 & 5 & 45.4 & 8 \\
\hline sions & 1 & 5 & 5 & 5 & 1 & & 1 & 5 & 5 & 1 & 5 & 5 & 5 & 0.2 & 1 & 55 & 50.2 & 9 \\
\hline mption & 5 & 10 & 1 & 5 & 5 & 1 & & 10 & 10 & 1 & 10 & 10 & 5 & 0.2 & 1 & $10 \mid$ & 84.2 & 15 \\
\hline & 0.2 & 0.2 & 0.2 & 0.1 & 0.2 & 0.2 & 0.1 & & 1 & 0.2 & 1 & 10 & 1 & 0.20 & 0.2 & 1 & 15.8 & 3 \\
\hline & 0.2 & 0.2 & 0.2 & 0.1 & 0.2 & 0.2 & 0.1 & 1 & & 1 & 1 & 10 & 1 & 0.2 & 1 & 1 & 17.4 & 3 \\
\hline $\begin{array}{l}\text { nal } \\
\text { C) }\end{array}$ & 0.2 & 5 & 1 & 1 & 1 & 1 & 1 & 5 & 1 & & 1 & 1 & 5 & 0.2 & 1 & 12 & 25.4 & 5 \\
\hline ance & 0.2 & 0.2 & 0.2 & & 0.2 & 0.2 & 0 & 1 & 2 & 1 & & 1 & 1 & 0.10 & 0.2 & 1 & 7.6 & 1 \\
\hline & 0.2 & 0.2 & 0.2 & 0.1 & 0.2 & 0.2 & 0.1 & 0.1 & 0.1 & 1 & 1 & & 0.2 & 0.10 & 0.2 & 0.2 & 4.1 & 1 \\
\hline $\begin{array}{l}\text { port } \\
\text { apatibility }\end{array}$ & 1 & 1 & 1 & 1 & 0.2 & 0.2 & 0.2 & 1 & 1 & 0.2 & 1 & 5 & & 0.2 & 1 & 1 & 15 & 3 \\
\hline 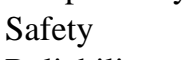 & 5 & 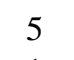 & 5 & 5 & 5 & 5 & 5 & 5 & 5 & 5 & 10 & 10 & 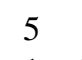 & & 5 & 10 & 90 & 16 \\
\hline Reliability & 5 & 1 & 1 & 1 & 1 & 1 & 1 & 5 & 1 & 1 & 5 & 5 & 1 & 0.2 & & 5 & 34.2 & 6 \\
\hline $\begin{array}{l}\text { Materials- } \\
\text { environment } \\
\text { interaction } \\
\text { (MEI) }\end{array}$ & 0.2 & 1 & 1 & 0.2 & 0.2 & 0.2 & 0.1 & 1 & 1 & 1 & 1 & 5 & 1 & 0.1 & 0.2 & & 13.2 & 2 \\
\hline
\end{tabular}

\section{Define the Problem}

The QFD diagram facilitates the translation of customer needs into engineering properties and to comprehend the effect of product design on downstream processes [39]-[45]. The QFD method takes the requirements of the customer and maps them onto product and process properties. Relationships between the various attributes are then found through a series of complementary matrices. Several of the management and planning tools presented earlier are fed into the QFD matrix; their contributions will be discussed in the following sections.

\section{House of quality}

It can be broken down into a number of 'rooms' which outline customer requirements, engineering characteristics, technical competitive assessment, customer competitive assessment, correlation matrix, relationship matrix, and target values [46],[47].

Customer Requirements: In the house of quality, the customer requirements are frequently called as the 'Whats' [47], [48]. This is essentially a list of what is desired to 
be accomplished by a project. The list of requirements is broken down into the same four categories as those identified in the affinity diagram: environmental, performance, economics, and operations. The importance rating for these requirements are given in the Prioritisation matrix in Table 1; therefore, they are not included in the QFD. However, upon review of Table 1 it is found that the environmental requirements are weighted the highest since the primary goals of this work fall under this category. Several of the performance requirements are also ranked relatively high including thrust, range, and payload. Each of these requirements is a part of propulsion architecture, which as identified in the interrelationship digraph, is the main driver in the current study.

Engineering Characteristics: Room 2 of the house of quality consists of the engineering characteristics, also known as the 'hows' [46], [49]. Here, certain engineering parameters are found, which are critical to developing an aircraft design capable of meeting $\mathrm{N}+3$ goals. The engineering characteristics are derived from the tree diagram in Figure 6.

Relationship matrix and correlation matrix: Rooms 3 and 4 of the QFD describe the association between the various requirements [47]. Figure 8 shows the relationship and correlation matrix, demonstrating the relationship between the various requirements. It captures both the relationship between the 'whats' and the 'hows' (Room 3) and the correlation between the engineering characteristics (Room 4). Room 3 shows the relationship matrix, whose primary goal is to identify the most important associations between the engineering characteristics and the customer requirements [47]-[50]. This is done by indicating a strong, moderate, or weak relationship with the appropriate symbol. If no relationship between the two requirements exists, the cell is left blank. The engineering characteristics which have a large number of strong relationships are material selection, Specific Fuel Consumption (SFC), and overall propulsion efficiency. As composites become more common in commercial aircraft and their applications rapidly grow, it is expected that material selection will have a greater significance than ever before, as its effects are seen in nearly all phases of aircraft design including performance, economics, and operations. SFC and overall propulsion efficiency are parameters which will provide a measure of how well the system achieves its goal of reducing fuel and energy consumption. Room 4, the roof of the House of Quality, shows the correlation matrix, which identifies the trade-offs that need to be made between the various engineering characteristics [46], [47]. The correlation can be positive (+), negative (-), or the cell left blank if there is no correlation. The desired direction of improvement for each characteristic is useful in identifying tradeoffs if the two characteristics are related. Several negative correlations are identified with aeroelastic flutter, which is a dynamic instability in aircraft wings that should be quickly mitigated without damage to the aircraft structure. In this situation, the correlation matrix provides an opportunity to focus on an innovative design to reduce aeroelastic flutter without compromising other important engineering characteristics such as aspect ratio.

Customer competitive assessment: A competitive assessment is performed to evaluate how well existing $\mathrm{N}+3$ concepts meet customer requirements [51]. The four best concepts identified are the Boeing SUGAR Volt [52], NASA N3-X Turboelectric Distributed Propulsion (TeDP), MIT Double Bubble, and Northrop Grumman SELECT [9], [30], [35], [52], [53]. The pictorial representation of these concepts can be found in resource [9]. Each of the competitor's concepts is evaluated against the customer requirements on a scale from 1 to 5 , with 1 being the lowest and 5 the highest, a concept could score. Based on this scale, the concepts are also ranked against one another. For example, preliminary fuel burn estimates for the NASA N3-X TeDP concept indicates 
that it has the highest reduction in fuel burn of the four concepts; therefore, it receives a score of 5 for energy consumption while all other concepts score 4 or below. Figure 9 shows the customer competitive assessment, demonstrating the performance of the four concepts toward customer requirements.

Technical competitive assessment and target values: The lower portion of the house of quality consists of target values and the technical competitive assessment [51], which are provided below in Figure 10. The target values for the engineering characteristics are first determined and compared to the baseline aircraft, the Boeing 777300ER. A technical competitive assessment is performed with the same concepts previously identified, but now each concept is evaluated against the engineering characteristics. The same scale is used as before to determine how well each concept meets the functional requirements and how they stack up against one another. Given that none of the concepts studied has yet to undergo significant testing and simulation, the technical evaluation is based primarily on the technologies each concept implements and the corresponding benefits those technologies provide. Figure 8 to Figure 10 are snapshots from the analysis tool/interface used for this work.

\section{QFD summary}

Stepping through the rooms of the QFD helps in developing a much deeper understanding of requirements and the challenges that exist in meeting those requirements. NASA has set very aggressive goals with $\mathrm{N}+3$, but the technologies necessary to achieve those goals have been identified. The customer requirements, established by NASA and future commercial airlines, are populated in room 1 of the House of Quality. The engineering characteristics required to answer the 'whats' are generated in room 2 and then the relationships between the 'hows' and the 'whats' is established in room 3. Identifying the requirements in rooms 1 and 2, laid out the objectives and methods for the goals of this work. Rooms 3 and 4 helps in identifying the most important parameters and the tradeoffs associated with negatively correlated engineering characteristics. The lower portion of the QFD helps in defining specific target values that move the concept towards achieving the overall goals of this work. Finally, competitive assessments are performed to analyze how well the current $\mathrm{N}+3$ concepts meet the customer and functional requirements. This helps in identifying key technologies that would allow the plan to apply the best ideas from existing concepts to achieve the optimal solution.

\section{Establish Value}

\section{Feasibility Criteria and Constraints}

Several advanced technologies are identified to successfully meet NASA N+3 goals in the required timeframe as per the study by Ashcraft et al. [9]. Some of these key technologies include acoustic liners, active tip clearance control, shape memory alloys, advanced airframe concept, electric motors, advanced combustors, composites, distributed propulsion, boundary layer ingestion, computational tool, batteries and fuel cells. Each technology is aimed at improving one or more of the N+3 objectives for reducing noise emissions, $\mathrm{NO}_{\mathrm{x}}$ emissions, and fuel/energy consumption. Ashcraft et al. [9] provide a technology assessment that helps in understanding the likelihood of each of the above-mentioned technologies and whether they will be ready for implementation in 
the N+3 timeframe. The said study also shows the potential benefits each technology is expected to provide in meeting $\mathrm{N}+3$ goals.

\begin{tabular}{|c|c|c|c|}
\hline \multicolumn{2}{|c|}{ Correlations } & \multicolumn{2}{|c|}{ Direction of Improvement } \\
\hline Positive & + & Maximize & $\Delta$ \\
\hline Negative & - & Target & $\diamond$ \\
\hline No Correlation & & Minimize & $\boldsymbol{\nabla}$ \\
\hline
\end{tabular}

\begin{tabular}{|rc|}
\hline Relationships & \\
\hline Strong & $\bullet$ \\
Moderate & $\bigcirc$ \\
Weak & $\nabla$ \\
\hline
\end{tabular}



Figure 8. Relationship and correlation matrix showing the relation between the various requirements. 


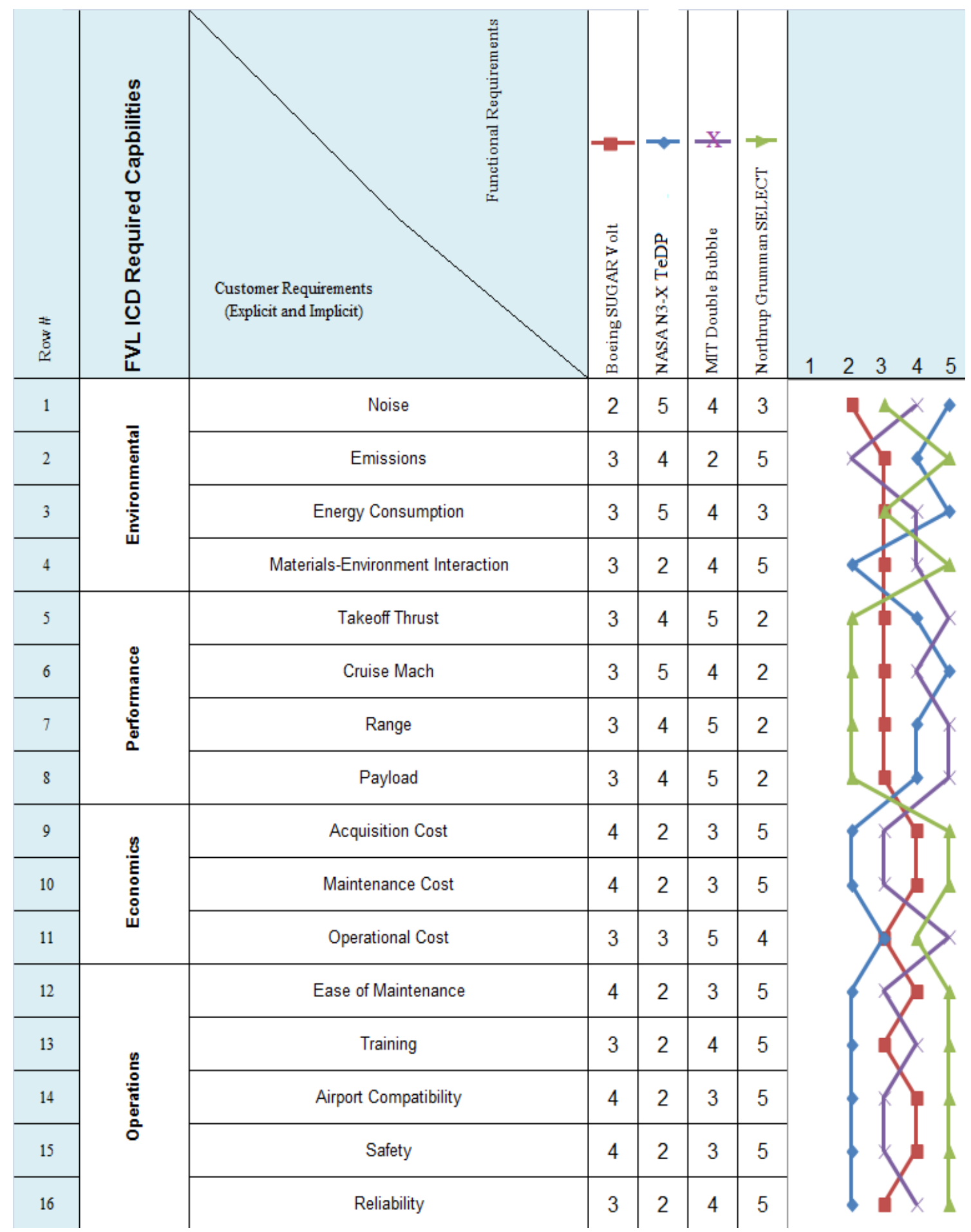

Figure 9. Customer competitive assessment showing the performance of the four concepts toward customer requirements. 


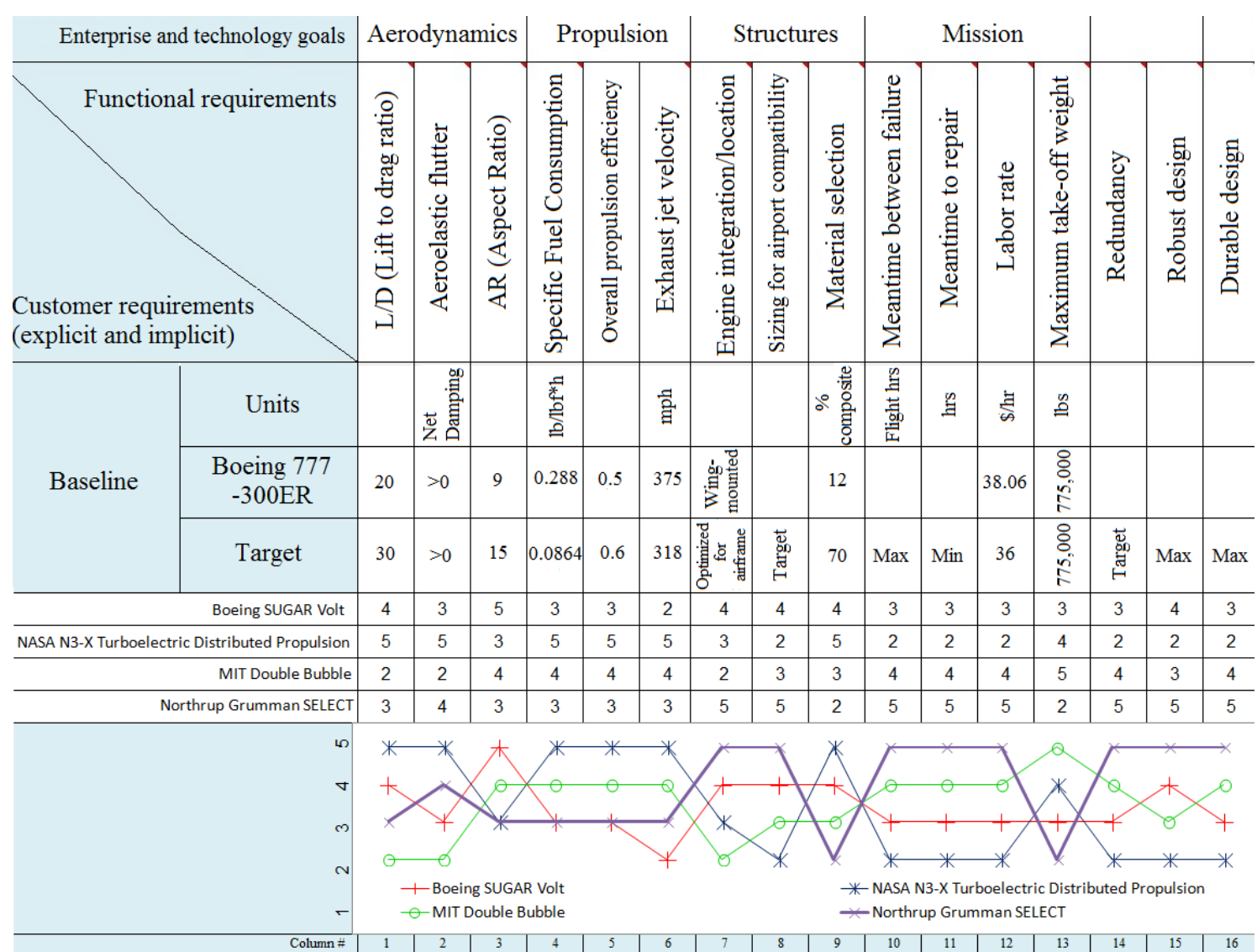

Figure 10. Technical competitive assessment and target values for the four concepts.

\section{Overall evaluation criterion $(O E C)$}

To establish the value, overall evaluation criterion (OEC) is used. This function is designed to combine different criteria into one single numerical index [54]. It shows the correlation between benefits and costs, and it can be used as a standardised basis for the objective comparison of design alternatives. The requirement characteristics defined in the QFD are used to formulate the OEC. The benefits consist of the environmental (En), performance $(\mathrm{Pe})$ and operations $(\mathrm{O})$ characteristics as they indicate the effectiveness of the system. On the other hand, the economics (Ec) represents the costs of the system. Every requirement characteristic is calculated in the first step while evaluating each criterion against a baseline value according to Table 2 and using the specific weights generated in Table 1. The desired direction of improvement is considered while determining whether the baseline value appears in the numerator or denominator. In the second step, all four values are combined to calculate the OEC for determining the benefit to cost ratio. A value equal to one suggests that the current aircraft design alternative equals the baseline aircraft. A value greater than one is therefore desired for future designs. The OEC can then be formulated as shown in Eq. (1), and it depends on variables such as Noise (N), Emissions (E), Energy Consumption (EC), Material Interaction (MI), Thrust (T), Cruise Mach (CM), Range (R), Payload (P), Ease of Maintenance (EM), Training (Tr), Airport Compatibility (AC), Safety (S), Reliability (Re), Acquisition Cost (AiCo), Maintenance Cost (MC), Operational Cost (OC), where subscript BL represents baseline (reference). 
$O E C=\frac{\frac{E n}{E n_{B L}}+\frac{P e}{P e_{B L}}+\frac{O}{O_{B L}}}{\frac{E c}{E c_{B L}}}$

$\frac{E n}{E n_{B L}}=0.08 \frac{N_{B L}}{N}+0.09 \frac{E_{B L}}{E}+0.15 \frac{E C_{B L}}{E C}+0.02 \frac{M I}{M I_{B L}}$

$\frac{P e}{P e_{B L}}=0.06 \frac{T}{T_{B L}}+0.05 \frac{C M}{C M_{B L}}+0.07 \frac{R}{R_{B L}}+0.1 \frac{P}{P_{B L}}$

$\frac{O}{O_{B L}}=0.01 \frac{E M}{E M_{B L}}+0.01 \frac{T_{B L}}{\operatorname{Tr}}+0.03 \frac{A C}{A C_{B L}}+0.16 \frac{S}{S_{B L}}+0.06 \frac{R e}{R e_{B L}}$

$\frac{E c}{E c_{B L}}=0.03 \frac{A i C o}{A i C o_{B L}}+0.03 \frac{M C}{M C_{B L}}+0.05 \frac{O C}{O C_{B L}}$

When using the baseline as well as the target values shown in Table 2, the OEC for the target design concept can be calculated. Inserting the values from Table 2 in Eq. (1) to (5), results in the OEC value of 21.748.

Table 2. Requirements and their respective baseline and target values to calculate the OEC.

\begin{tabular}{|c|c|c|c|c|c|}
\hline Requirements & Element & Weight & Baseline & Target & Units \\
\hline \multirow{4}{*}{ Environmental } & Noise & .08 & 150 & 79 & $\begin{array}{c}\mathrm{dB}(\text { takeoff at } \\
25 \mathrm{~m})\end{array}$ \\
\hline & Emissions & .09 & 11 & $<2.75$ & ppm \\
\hline & $\begin{array}{c}\text { Energy } \\
\text { consumption }\end{array}$ & .15 & 0.288 & $<0.086$ & $\mathrm{lb} / \mathrm{lbf} * \mathrm{hr}$ \\
\hline & $\begin{array}{l}\text { Materials- } \\
\text { environment } \\
\text { interaction }\end{array}$ & .02 & 1 & $+10 \%$ & - \\
\hline \multirow{4}{*}{ Performance } & Takeoff thrust & .06 & 115,300 & 116,000 & lbs (per engine) \\
\hline & Cruise speed & .05 & 0.84 & 0.8 & $\begin{array}{l}\text { Mach Number } \\
\text { (M) }\end{array}$ \\
\hline & Range & .07 & 7825 & 7900 & $\begin{array}{c}\text { Nautical Miles } \\
\text { (NM) }\end{array}$ \\
\hline & Payload & .10 & 151,000 & 155,000 & lbs \\
\hline \multirow{3}{*}{ Economics } & Acquisition cost & .03 & $\begin{array}{l}\$ 298 \\
\text { million }\end{array}$ & $\begin{array}{l}\$ 295 \\
\text { million }\end{array}$ & U.S. Dollars \\
\hline & $\begin{array}{l}\text { Maintenance } \\
\text { cost }\end{array}$ & .03 & $\$ 3900$ & $\$ 3400$ & $\begin{array}{c}\text { U.S. } \\
\text { Dollars/hour }\end{array}$ \\
\hline & Operational cost & .05 & $\$ 17$ & $\$ 6$ & $\begin{array}{c}\text { U.S. } \\
\text { Dollars/NM }\end{array}$ \\
\hline \multirow{5}{*}{ Operations } & $\begin{array}{c}\text { Ease of } \\
\text { maintenance }\end{array}$ & .01 & 1 & $+10 \%$ & - \\
\hline & Training & .01 & 1 & $-15 \%$ & - \\
\hline & $\begin{array}{c}\text { Airport } \\
\text { compatibility }\end{array}$ & .03 & 1 & $+2 \%$ & - \\
\hline & Safety & .16 & 1 & $+1 \%$ & - \\
\hline & Reliability & .06 & 1 & $+10 \%$ & - \\
\hline
\end{tabular}




\section{Generate Alternatives}

A morphological matrix is a tool used for producing alternatives [55]. It helps in giving a systematic method to produce a high number of combinations/cases, which include several unique options [55]. The morphological matrix is given in Table 3. Four main vehicle characteristics including the necessary sub-characteristics are considered while making a morphological matrix for this work. Numerous possible alternatives for each of the sub-characteristic properties are listed. As discussed earlier, the four concepts SUGAR Volt (Concept 1), NASA N3-X TeDP (Concept 2), MIT Double Bubble (Concept 3) and Northrop Grumman SELECT (Concept 4) are considered as alternatives, with the baseline model Boeing 777300 ER. The characteristics and sub-characteristics of each concept are listed against one to one basis. The alternatives are evaluated after generating them on the sub-characteristic basis in the next section. The system/physical alternatives for hybrid-electric aircraft are shown in Table 4.

Table 3. Morphological matrix for generating alternatives.

\begin{tabular}{|c|c|c|c|c|c|c|c|c|}
\hline  & 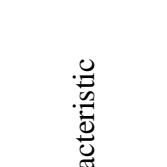 & \multicolumn{6}{|c|}{ Alternatives } & $\overline{0}$ \\
\hline \multirow{9}{*}{ 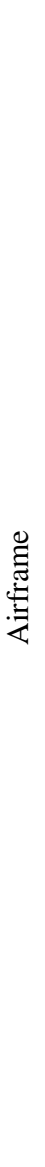 } & Type & $\begin{array}{c}\text { Tube \& } \\
\text { Wing }\end{array}$ & $\begin{array}{c}\text { Hybrid } \\
\text { Wing } \\
\text { Body }\end{array}$ & $\begin{array}{l}\text { Twin Tube } \\
\& \text { Wing }\end{array}$ & $\begin{array}{c}\text { Tube \& } \\
\text { Joined } \\
\text { Wing }\end{array}$ & $\begin{array}{c}\text { Tube \& } \\
\text { Strut } \\
\text { Braced } \\
\text { Wing }\end{array}$ & & 5 \\
\hline & $\begin{array}{c}\text { Wing } \\
\text { Location }\end{array}$ & High & Mid & Low & Parasol & & & 4 \\
\hline & $\begin{array}{c}\text { Wing } \\
\text { Support } \\
\text { Structure }\end{array}$ & $\begin{array}{c}\text { Strut } \\
\text { Braced }\end{array}$ & $\begin{array}{c}\text { Fuselage } \\
\& \text { Tail } \\
\text { Section } \\
\text { Supported }\end{array}$ & Cantilever & $\begin{array}{c}\text { Strut } \\
\text { Braced \& } \\
\text { Cantilever }\end{array}$ & & & 4 \\
\hline & $\begin{array}{l}\text { No. of } \\
\text { Wings }\end{array}$ & 1 & 2 & 3 & & & & 3 \\
\hline & $\begin{array}{l}\text { Wing } \\
\text { Folding }\end{array}$ & Yes & No & & & & & 2 \\
\hline & $\begin{array}{c}\text { Tail } \\
\text { Arrangeme } \\
\text { nt }\end{array}$ & $\begin{array}{c}\text { Conventio } \\
\text { nal }\end{array}$ & Pi Tail & H Tail & Twin Tail & Tailless & Cruciform & 6 \\
\hline & Material & $\begin{array}{c}\text { Aluminiu } \\
\mathrm{m}\end{array}$ & Composite & Titanium & $\begin{array}{c}\text { Aluminu } \\
\text { m/Compo } \\
\text { site } \\
\text { Hybrid }\end{array}$ & Steel & & 5 \\
\hline & $\begin{array}{l}\text { Landing } \\
\text { Gear Type }\end{array}$ & Tricycle & $\begin{array}{c}\text { Wing } \\
\text { Retractable }\end{array}$ & $\begin{array}{c}\text { Fuselage } \\
\text { Retractabl } \\
\text { e }\end{array}$ & $\begin{array}{c}\text { Wing } \\
\text { Supported }\end{array}$ & $\begin{array}{c}\text { Taildragg } \\
\text { er }\end{array}$ & Fixed & 6 \\
\hline & $\begin{array}{l}\text { Dihedral } \\
\text { Angle }\end{array}$ & Dihedral & Anhedral & Neutral & Gull Wing & $\begin{array}{c}\text { Inverted } \\
\text { Gull } \\
\text { Wing }\end{array}$ & Variable & 6 \\
\hline
\end{tabular}




\begin{tabular}{|c|c|c|c|c|c|c|c|c|}
\hline \multirow{13}{*}{ 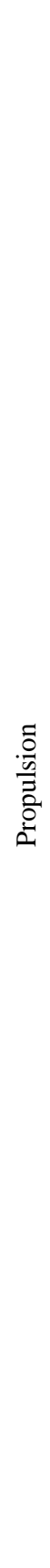 } & Type & $\begin{array}{c}\text { Conventio } \\
\text { nal }\end{array}$ & $\begin{array}{l}\text { Hybrid- } \\
\text { Electric }\end{array}$ & $\begin{array}{c}\text { All- } \\
\text { Electric }\end{array}$ & & & & 3 \\
\hline & $\begin{array}{c}\text { Power } \\
\text { Generation } \\
\text { Device }\end{array}$ & Fuel Cells & $\begin{array}{c}\text { Gas } \\
\text { Generator }\end{array}$ & Solar & & & & 3 \\
\hline & $\begin{array}{l}\text { Thrust } \\
\text { Generation } \\
\text { Device }\end{array}$ & $\begin{array}{c}\text { Conventio } \\
\text { nal } \\
\text { Turbofan }\end{array}$ & $\begin{array}{l}\text { Geared } \\
\text { Turbofan }\end{array}$ & $\begin{array}{l}\text { Open } \\
\text { Rotor }\end{array}$ & $\begin{array}{c}\text { Electric } \\
\text { Fan }\end{array}$ & Turbojet & & 5 \\
\hline & $\begin{array}{l}\text { Power } \\
\text { Storage } \\
\text { Device }\end{array}$ & Batteries & Flywheel & Capacitor & & & & 3 \\
\hline & $\begin{array}{c}\text { Power } \\
\text { Transmissi } \\
\text { on Device }\end{array}$ & $\begin{array}{l}\text { Conventio } \\
\text { nal } \\
\text { Conductin } \\
\text { g Motors }\end{array}$ & $\begin{array}{l}\text { Supercond } \\
\text { ucting } \\
\text { Motors }\end{array}$ & & & & & 2 \\
\hline & Fuel & Jet-A & Bio-Fuel & $\begin{array}{c}\text { Liquid } \\
\text { Hydrogen }\end{array}$ & & & & 3 \\
\hline & Location & $\begin{array}{l}\text { Below } \\
\text { Wing }\end{array}$ & $\begin{array}{l}\text { Above } \\
\text { Wing }\end{array}$ & Wingtip & Tail & $\begin{array}{c}\text { Wing } \\
\text { Integrate }\end{array}$ & $\begin{array}{c}\text { Tail } \\
\text { Integrated }\end{array}$ & 6 \\
\hline & $\begin{array}{l}\text { No. of } \\
\text { Engines }\end{array}$ & 1 & 2 & 3 & 4 & & & 4 \\
\hline & $\begin{array}{c}\text { RAT (Ram } \\
\text { Air } \\
\text { Turbine) }\end{array}$ & Yes & No & & & & & 2 \\
\hline & APU & $\begin{array}{c}\text { Conventio } \\
\text { nal } \\
\text { Turbine }\end{array}$ & Fuel Cells & Solar & $\begin{array}{l}\text { Power } \\
\text { Storage } \\
\text { Device }\end{array}$ & & & 4 \\
\hline & $\begin{array}{c}\text { Noise } \\
\text { Reduction }\end{array}$ & $\begin{array}{l}\text { Airframe } \\
\text { Shielding }\end{array}$ & $\begin{array}{l}\text { Chevron } \\
\text { Nozzles }\end{array}$ & $\begin{array}{l}\text { Acoustic } \\
\text { Liner }\end{array}$ & $\begin{array}{c}\text { Increased } \\
\text { Bypass } \\
\text { Ratio }\end{array}$ & & & 4 \\
\hline & Combustor & $\begin{array}{l}\text { Reverse- } \\
\text { Flow }\end{array}$ & $\begin{array}{l}\text { Lean } \\
\text { Direct } \\
\text { Injection } \\
\text { (LDI) }\end{array}$ & $\begin{array}{c}\text { Lean } \\
\text { Premixed } \\
\text { Pre- } \\
\text { vaporized } \\
\text { (LPP) }\end{array}$ & $\begin{array}{c}\text { Rich- } \\
\text { Burn/Quic } \\
\text { k- } \\
\text { Quench/L } \\
\text { ean-Burn } \\
\text { (RQL) }\end{array}$ & & & 4 \\
\hline & $\begin{array}{l}\text { Auxiliary } \\
\text { Units }\end{array}$ & $\begin{array}{l}\text { Catalytic } \\
\text { Converters }\end{array}$ & $\begin{array}{l}\text { Thrust } \\
\text { Reversers }\end{array}$ & & & & & 2 \\
\hline \multirow{5}{*}{ 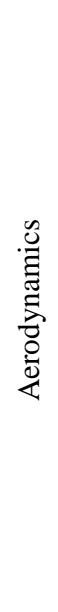 } & $\begin{array}{l}\text { Wingtip } \\
\text { Design }\end{array}$ & $\begin{array}{c}\text { Squared } \\
\text { Off }\end{array}$ & Rounded & $\begin{array}{l}\text { Blended } \\
\text { Winglet }\end{array}$ & $\begin{array}{l}\text { Wingtip } \\
\text { Fence }\end{array}$ & Raked & Spiroid & 6 \\
\hline & $\begin{array}{l}\text { Aspect } \\
\text { Ratio }\end{array}$ & Low & Moderate & High & & & & 3 \\
\hline & $\begin{array}{l}\text { Flow } \\
\text { Control }\end{array}$ & $\begin{array}{l}\text { Boundary } \\
\text { Layer } \\
\text { Ingestion } \\
\text { (BLI) }\end{array}$ & $\begin{array}{l}\text { Vortex } \\
\text { Generator }\end{array}$ & Suction & Blowing & Spoilers & & 5 \\
\hline & $\begin{array}{l}\text { Leading } \\
\text { Edge }\end{array}$ & $\begin{array}{l}\text { Krueger } \\
\text { Flap }\end{array}$ & $\begin{array}{l}\text { Leading } \\
\text { Edge } \\
\text { Droop }\end{array}$ & Slats & Slots & & & 4 \\
\hline & $\begin{array}{l}\text { Trailing } \\
\text { Edge }\end{array}$ & Plain Flap & Split Flap & $\begin{array}{l}\text { Slotted } \\
\text { Flap }\end{array}$ & $\begin{array}{l}\text { Fowler } \\
\text { Flap }\end{array}$ & $\begin{array}{l}\text { Multi- } \\
\text { Slotted }\end{array}$ & $\begin{array}{l}\text { Adaptive } \\
\text { Dropped } \\
\text { Hinge Flap }\end{array}$ & 6 \\
\hline
\end{tabular}




\begin{tabular}{|c|c|c|c|c|c|c|c|}
\hline & & & & & & $\begin{array}{l}\text { Fowler } \\
\text { Flap }\end{array}$ & \\
\hline & $\begin{array}{l}\text { Wing } \\
\text { Sweep }\end{array}$ & Straight & $\begin{array}{c}\text { Swept } \\
\text { Rearward }\end{array}$ & $\begin{array}{l}\text { Swept } \\
\text { Forward }\end{array}$ & $\begin{array}{c}\text { Variable } \\
\text { Sweep }\end{array}$ & & 4 \\
\hline ฮี & $\begin{array}{l}\text { No. of } \\
\text { Aisles }\end{array}$ & 1 & 2 & 3 & 4 & 5 & 5 \\
\hline 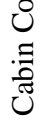 & $\begin{array}{l}\text { No. of } \\
\text { Floors }\end{array}$ & 1 & 2 & & & & 2 \\
\hline
\end{tabular}

Table 4. System/Physical alternatives for hybrid-electric aircraft.

\begin{tabular}{|c|c|c|c|c|c|c|}
\hline & & Baseline & Concept 1 & Concept 2 & Concept 3 & Concept 4 \\
\hline \multirow{10}{*}{  } & Type & Tube \& Wing & $\begin{array}{c}\text { Tube \& Strut Braced } \\
\text { Wing }\end{array}$ & $\begin{array}{l}\text { Hybrid Wing } \\
\text { Body }\end{array}$ & $\begin{array}{l}\text { Twin Tube \& } \\
\text { Wing }\end{array}$ & Tube \& Wing \\
\hline & Wing Location & Low & High & Mid & Low & Low \\
\hline & $\begin{array}{l}\text { Wing Support } \\
\text { Structure }\end{array}$ & Cantilever & $\begin{array}{l}\text { Strut Braced \& } \\
\text { Cantilever }\end{array}$ & Cantilever & Cantilever & Cantilever \\
\hline & No. of Wings & 1 & 1 & 1 & 1 & 1 \\
\hline & Wing Folding & No & Yes & Yes & No & No \\
\hline & $\begin{array}{c}\text { Tail } \\
\text { Arrangement }\end{array}$ & Conventional & Conventional & Tailless & Pi Tail & Conventional \\
\hline & Material & Aluminium & $\begin{array}{c}\text { Aluminum/ Composite } \\
\text { Hybrid }\end{array}$ & $\begin{array}{l}\text { Aluminum/ } \\
\text { Composite } \\
\text { Hybrid }\end{array}$ & $\begin{array}{l}\text { Aluminium/ } \\
\text { Composite } \\
\text { Hybrid }\end{array}$ & $\begin{array}{l}\text { Aluminium/ } \\
\text { Composite } \\
\text { Hybrid }\end{array}$ \\
\hline & Landing Gear & Fuselage & & Wing & Fuselage & Fuselage \\
\hline & Type & Retractable & Fuselage Retra & Retractable & Retractable & Retractable \\
\hline & Dihedral Angle & Dihedral & Dihedral & Neutral & Dihedral & Dihedral \\
\hline \multirow{14}{*}{ 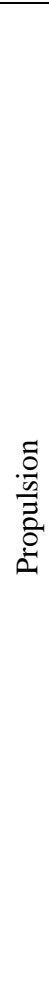 } & $\begin{array}{l}\text { Type } \\
\text { Power }\end{array}$ & Conventional & Hybrid-Electric & Hybrid-Electric & Hybrid-Electric & Hybrid-Electric \\
\hline & $\begin{array}{l}\text { Generation } \\
\text { Device }\end{array}$ & Gas Generator & Gas Generator & Gas Generator & Gas Generator & Gas Generator \\
\hline & $\begin{array}{l}\text { Thrust } \\
\text { Generation } \\
\text { Device }\end{array}$ & $\begin{array}{l}\text { Conventional } \\
\text { Turbofan }\end{array}$ & Geared Turbofan & $\begin{array}{l}\text { Conventional } \\
\text { Turbofan \& } \\
\text { Electric Fans }\end{array}$ & $\begin{array}{l}\text { Conventional } \\
\text { Turbofan \& } \\
\text { Electric Fan }\end{array}$ & Geared Turbofan \\
\hline & $\begin{array}{l}\text { Power Storage } \\
\text { Device }\end{array}$ & None & Batteries & Batteries & Batteries & Batteries \\
\hline & Power & & Conventional Conducting & Conventional & Conventional & Conventional \\
\hline & $\begin{array}{l}\text { Transmission } \\
\text { Device }\end{array}$ & None & Motors & $\begin{array}{l}\text { Conducting } \\
\text { Motors }\end{array}$ & $\begin{array}{l}\text { Conducting } \\
\text { Motors }\end{array}$ & $\begin{array}{l}\text { Conducting } \\
\text { Motors }\end{array}$ \\
\hline & Fuel & Jet-A & Jet-A & Jet-A & Jet-A & Jet-A \\
\hline & Location & Below Wing & Below Wing & Tail Integrated & Tail Integrated & Below Wing \\
\hline & No. of Engines & 2 & 2 & 1 & 1 & 2 \\
\hline & $\begin{array}{l}\text { RAT (Ram Air } \\
\text { Turbine) }\end{array}$ & Yes & Yes & Yes & Yes & Yes \\
\hline & APU & $\begin{array}{l}\text { Conventional } \\
\text { Turbine }\end{array}$ & Conventional Turbine & $\begin{array}{l}\text { Conventional } \\
\text { Turbine }\end{array}$ & $\begin{array}{l}\text { Conventional } \\
\text { Turbine }\end{array}$ & $\begin{array}{l}\text { Conventional } \\
\text { Turbine }\end{array}$ \\
\hline & $\begin{array}{l}\text { Noise } \\
\text { Reduction }\end{array}$ & Acoustic Liners & $\begin{array}{c}\text { Chevron } \\
\text { Nozzles/Acoustic } \\
\text { Liner/Increased Bypass } \\
\text { Ratio }\end{array}$ & $\begin{array}{c}\text { Airframe } \\
\text { Shielding \& } \\
\text { Acoustic Liner }\end{array}$ & $\begin{array}{c}\text { Airframe } \\
\text { Shielding \& } \\
\text { Acoustic Liner }\end{array}$ & $\begin{array}{c}\text { Chevron } \\
\text { Nozzles/Acoustic } \\
\text { Liner/Increased } \\
\text { Bypass Ratio }\end{array}$ \\
\hline & Combustor & $\begin{array}{l}\text { Lean Direct } \\
\text { Injection }\end{array}$ & $\begin{array}{l}\text { Lean Premixed Pre- } \\
\text { vaporized }\end{array}$ & $\begin{array}{c}\text { Lean Premixed } \\
\text { Pre-vaporized }\end{array}$ & $\begin{array}{l}\text { Lean Premixed } \\
\text { Pre-vaporized }\end{array}$ & $\begin{array}{l}\text { Lean Premixed } \\
\text { Pre-vaporized }\end{array}$ \\
\hline & Auxiliary Units & $\begin{array}{c}\text { Thrust } \\
\text { Reversers }\end{array}$ & Thrust Reversers & $\begin{array}{c}\text { Thrust } \\
\text { Reversers }\end{array}$ & $\begin{array}{c}\text { Thrust } \\
\text { Reversers }\end{array}$ & Thrust Reversers \\
\hline
\end{tabular}




\begin{tabular}{|c|c|c|c|c|c|c|}
\hline \multirow{7}{*}{ 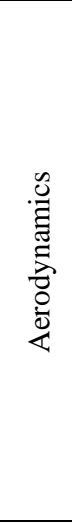 } & $\begin{array}{c}\text { Wingtip Design } \\
\text { Aspect Ratio }\end{array}$ & Raked & Blended Winglet & Blended & $\begin{array}{l}\text { Blended } \\
\text { Winglet }\end{array}$ & Raked \\
\hline & 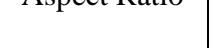 & Hiा & Ming & Noverate & Boundary Layer & Mgnt \\
\hline & Flow Control & Spoilers & Suction/Blowing/Spoilers & $\begin{array}{l}\text { Boundary Layer } \\
\text { Ingestion, } \\
\text { Suction, \& } \\
\text { Spoilers }\end{array}$ & $\begin{array}{l}\text { Ingestion, } \\
\text { Suction, } \\
\text { Blowing \& } \\
\text { Spoilers }\end{array}$ & $\begin{array}{c}\text { Suction, Blowing } \\
\quad \& \text { Spoilers }\end{array}$ \\
\hline & Leading Edge & Slat & Krueger Flap & Krueger Flap & Krueger Flap & Krueger Flap \\
\hline & & Multi-Slotted & Adaptive Dropped Hinge & $\begin{array}{l}\text { Adaptive } \\
\text { Dronned Hing }\end{array}$ & Adaptive & Adaptive \\
\hline & Trailıng Edge & Fowler Flap & Flap & $\begin{array}{c}\text { Dropped Hinge } \\
\text { Flap }\end{array}$ & $\begin{array}{c}\text { Dropped Hinge } \\
\text { Flap }\end{array}$ & $\begin{array}{l}\text { Dropped Hinge } \\
\text { Flap }\end{array}$ \\
\hline & Wing Sweep & $\begin{array}{c}\text { Swept } \\
\text { Rearward }\end{array}$ & Straight & $\begin{array}{c}\text { Swept } \\
\text { Rearward }\end{array}$ & Straight & Swept Rearward \\
\hline \multirow{2}{*}{ ن } & No. of Aisles & 2 & 2 & 5 & 2 & 2 \\
\hline & No. of Floors & 1 & 1 & 1 & 1 & 1 \\
\hline
\end{tabular}

\section{Evaluation and Decision}

All four concepts developed in the previous step are compared in order to find the best option. Based on the definitions made in Table 4, each concept is evaluated. The goal is to find the best concept that should be focused on future studies.

\section{Pugh matrix}

The system requirements defined in the QFD are used as evaluation criteria. Within the Pugh Matrix [56], [57] each future aircraft concept is compared against a baseline aircraft, the Boeing 777-300ER, in this case. Each concept is categorized as being better $(+1)$, the same $(0)$ or worse $(-1)$ than the baseline, for each evaluation criterion. By using this method, the weights generated in Table 1 are neglected. The best concept is determined by adding up all assigned values for each column representing one concept. The alternative with the highest value is then chosen as the best alternative. Table 5 shows the respective analysis. It can be seen from Table 5 that the blended wing with hybrid-electric propulsion (concept alternative 2), is the best concept.

\section{TOPSIS}

As discussed in the previous section, while using the Pugh Matrix the weights of each criterion are neglected. Each concept is also evaluated against a baseline aircraft instead of being compared to each other. In order to improve the evaluation and decision process, a more complex method is used. TOPSIS is an analytical method for making decisions in a multi-criteria scenario [58]. It allows trade-offs and the allocated weights. This method defines the best concept as being closest to the positive ideal solution and the farthest from the negative ideal solution [59]. The result is, therefore, more trustworthy than the result of the Pugh Matrix. In the first step, each concept is mapped against the evaluation criteria. An interval scale from 1 to 9 is used as shown in Table 6 (Score value: 1 to 9). For a criterion that needs to be maximized the value 9 is the best solution while for a criterion that needs to be minimised the value 1 is the best solution. Within the next step, the weights resulting from the analysis in Table 1 are introduced into the calculation. 
Furthermore, the attributed values are normalised by dividing them by the norm of the total outcome vector of the respective criterion. The results of the calculation can be seen in Table 7 (Normalised). Based on the calculated values a positive ideal solution, as well as a negative ideal solution, are generated. In this step, the direction of improvement plays an important role. The positive ideal solution is generated using the following values: (a) Criterion should be maximized (arrow upward): the highest value of all concepts; (b) Criterion should be minimised (arrow downward): the lowest value of all concepts. The same principle is used to generate a negative ideal solution. The selection process for the values is vice versa: (a) Criterion should be maximized (arrow upward): the lowest value of all concepts; (b) Criterion should be minimised (arrow downward): the highest value of all concepts.

The final and last step of the TOPSIS calculation comprises of calculating the separation of every alternative from the ideal point as well as the relative closeness. By using n-dimensional Euclidean distance, the distance of each point is calculated [60]. The separation of every concept from the positive ideal solution or negative ideal solution is then computed according to Eq. (6), where AV is the Alternative Value, (Pos/Neg) I.V is Positive/Negative Ideal Value. Also, the superscript '-' denotes the distance to the negative ideal solution while the superscript ' $*$ ' denotes the distance to the positive ideal solution. Based on those values, the relative closeness of every concept to the positive ideal solution can be calculated by Eq. (7).

$$
\begin{aligned}
& S_{i}^{* /-}=\sqrt{\sum(A V-(\text { Pos } / N e g) I . V)^{2}} \\
& C_{i}=\frac{S_{i}^{-}}{S_{i}^{*}+S_{i}^{-}}
\end{aligned}
$$

\begin{tabular}{|c|c|c|c|c|c|c|}
\hline Evaluation Crit & & Baseline & Concept 1 & Concept 2 & Concept 3 & Concept 4 \\
\hline \multirow{4}{*}{ Environmental } & Noise & \multirow{4}{*}{$\begin{array}{l}\Xi \\
\stackrel{\Xi}{\Xi} \\
\stackrel{\Xi}{\Xi}\end{array}$} & 0 & 1 & 1 & 0 \\
\hline & Emissions & & 1 & 1 & 1 & 1 \\
\hline & \begin{tabular}{|l} 
Energy \\
consumption
\end{tabular} & & 1 & 1 & 1 & 1 \\
\hline & $\begin{array}{l}\text { Materials-environment } \\
\text { interaction }\end{array}$ & & -1 & -1 & -1 & -1 \\
\hline \multirow{4}{*}{ Performance } & Takeoff thrust & \multirow{4}{*}{ 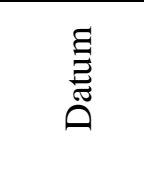 } & 0 & 1 & 1 & 0 \\
\hline & Cruise speed & & -1 & 1 & -1 & 0 \\
\hline & Range & & 1 & 1 & 0 & 0 \\
\hline & Payload & & 1 & 1 & 1 & 0 \\
\hline \multirow{3}{*}{ Economics } & Acquisition cost & \multirow{3}{*}{ 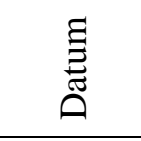 } & -1 & -1 & -1 & 0 \\
\hline & Maintenance cost & & -1 & -1 & -1 & 0 \\
\hline & Operational cost & & 1 & 1 & 1 & 1 \\
\hline \multirow{5}{*}{ Operations } & Ease of maintenance & \multirow{5}{*}{$\begin{array}{l}\Xi_{\Xi}^{\Xi} \\
\stackrel{\Xi}{\tilde{D}}\end{array}$} & 0 & -1 & -1 & 0 \\
\hline & Training & & -1 & -1 & -1 & -1 \\
\hline & Airport Compatibility & & 1 & 1 & -1 & 0 \\
\hline & Safety & & 0 & -1 & -1 & 0 \\
\hline & Reliability & & 1 & 0 & 0 & 1 \\
\hline \multicolumn{3}{|l|}{ Total } & 2 & 3 & -2 & 2 \\
\hline
\end{tabular}

Table 5. Pugh Matrix for the evaluation of four concepts. 
Table 6. Evaluation of each concept for the TOPSIS approach.

\begin{tabular}{|c|c|c|c|c|c|c|c|c|c|c|c|c|c|c|c|c|}
\hline \multirow{2}{*}{$\begin{array}{l}\text { Direction of } \\
\text { Improvement }\end{array}$} & \multicolumn{6}{|c|}{ Environmental } & \multicolumn{3}{|c|}{ Performance } & \multicolumn{3}{|c|}{ Economics } & \multicolumn{4}{|c|}{ Operations } \\
\hline & $\downarrow$ & $\downarrow$ & $\downarrow$ & $\uparrow$ & $\uparrow$ & $\uparrow$ & $\uparrow$ & $\uparrow$ & $\downarrow$ & $\downarrow$ & $\downarrow$ & $\uparrow$ & $\downarrow$ & $\uparrow$ & $\uparrow$ & $\uparrow$ \\
\hline Alternative & $\begin{array}{l}0 \\
.0 \\
0 \\
z\end{array}$ & 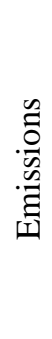 & 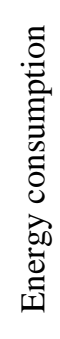 & 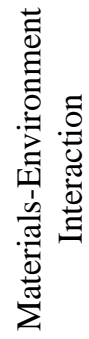 & 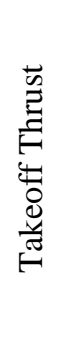 & 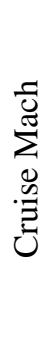 & 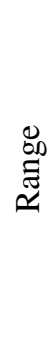 & $\frac{\vec{J}}{\frac{\pi}{\lambda}}$ & 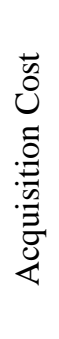 & 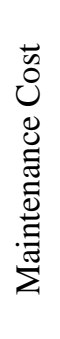 & 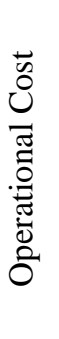 & 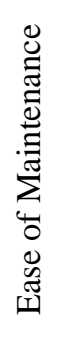 & 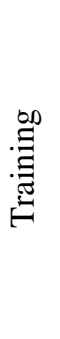 &  &  & 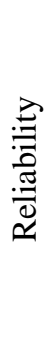 \\
\hline Concept 1 & 3 & 3 & 3 & 5 & 5 & 3 & 7 & 7 & 7 & 7 & 3 & 3 & 7 & 7 & 9 & 7 \\
\hline Concept 2 & 1 & 1 & 1 & 3 & 7 & 7 & 9 & 9 & 9 & 9 & 1 & 1 & 9 & 7 & 7 & 5 \\
\hline Concept 3 & 1 & 1 & 1 & 3 & 7 & 1 & 5 & 9 & 7 & 7 & 1 & 1 & 9 & 3 & 7 & 5 \\
\hline Concept 4 & 3 & 3 & 3 & 5 & 5 & 5 & 5 & 5 & 5 & 5 & 3 & 3 & 7 & 5 & 9 & 7 \\
\hline
\end{tabular}

Table 7. Evaluation of each concept for the TOPSIS approach (normalised values).



A high value of $C_{i}$ means that the respective alternative is very close to the positive ideal solution. The concept with the highest value is, therefore, the best concept. Table 8 shows the results of TOPSIS process. It can be observed that concept 2 , the blended wing 
concept with hybrid-electric propulsion, is again the best of all alternatives considered. This confirms the results of the 'Pugh Matrix' method.

Table 8. TOPSIS calculation results: Relative closeness to the positive ideal solution.

\begin{tabular}{lccc}
\hline Alternative & $S_{i}^{*}$ & $S_{i}^{-}$ & $C_{i}$ \\
\hline Concept 1 & 0.0937 & 0.0328 & 0.2594 \\
Concept 2 & 0.0260 & 0.1014 & 0.7958 \\
Concept 3 & 0.0468 & 0.0933 & 0.6662 \\
Concept 4 & 0.0962 & 0.0344 & 0.2632 \\
\hline
\end{tabular}

\section{Decision}

From the Pugh Matrix and TOPSIS, it can be observed that concept 2, the blended wing aircraft with hybrid-electric propulsion, is superior to the other three concepts considered in this work. It is, therefore, the best alternative to meet the NASA N+3 design goals.

\section{CONCLUSION}

As the commercial aviation industry continues to grow, more sophisticated and revolutionary aircraft concepts will be required to meet stringent noise, emissions, and fuel/energy consumption constraints despite increased demand for air travel. With a rising concern for environmental protection, aero-propulsion engineers will be forced to look beyond technological innovations in the combustion realm towards emission-free (directuse), electric propulsion systems. Hybrid-electric aircraft, such as the blended wing hybrid-electric concept presented in this work, can be the future of the commercial aviation industry that will allow aircraft manufacturers to achieve rigorous noise, emissions, and fuel/energy consumption goals like those established in NASA N+3. This work followed the Georgia Tech Integrated Product-Process Development (IPPD) method to conceive a commercial aircraft which can meet the rigorous $\mathrm{N}+3$ goals set by NASA. The benefits of such a design process are that it allows design changes to be made early in the life of the project, thus reducing life cycle costs. The project management and planning need to be done using a Systems Engineering Management Plan (SEMP) to ensure that such a time-bound project remains on schedule and meets the target completion date, which accounts towards phase two of the project. By using the critical path method, an earliest possible entry into service date can be projected. Additionally, further development of the blended wing hybrid-electric concept would move towards research in developing the appropriate technologies that will allow the $\mathrm{N}+3$ goals to be achieved. Subsequently, the conceptual, preliminary, and detailed design phases would ensue as the concept progresses towards entry into service.

\section{ACKNOWLEDGEMENT}

I would like to thank the team at Sanicle, and the donors who have supported me and our research work all the way. 


\section{REFERENCES}

[1] IATA. IATA - 2036 Forecast Reveals Air Passengers Will Nearly Double to 7.8 Billion. Retrieved from https://www.iata.org/pressroom/pr/Pages/2017-10-2401.aspx.; 5 January, 2019.

[2] Boeing. Current market outlook 2017-2036. Retrieved from http://www.boeing.com/resources/boeingdotcom/commercial/market/currentmarket-outlook-2017/assets/downloads/2017-cmo-6-19.pdf; 2 July, 2019.

[3] Air Transport Action Group. Aviation: Benefits Beyond Borders. Retrieved from https://aviationbenefits.org/media/166344/abbb18_full-report_web.pdf; 2 July, 2019.

[4] IATA. Fact Sheet: Climate Change \& CORSIA. Retrieved from https://www.iata.org/pressroom/facts_figures/fact_sheets/Documents/fact-sheetclimate-change.pdf; 2 July, 2019.

[5] IATA. Industry Statistics Fact Sheet. 2018. Retrieved from https://www.iata.org/pressroom/facts_figures/fact_sheets/Documents/fact-sheetindustry-facts.pdf; 2 July, 2019.

[6] Lee DS. The current state of scientific understanding of the non-CO 2 effects of aviation on climate. 2018. Retrieved from https://assets.publishing.service. gov.uk/government/uploads/system/uploads/attachment_data/file/813342/nonCO2-effects-report.pdf; 2 July, 2019.

[7] Jagtap SS. Sustainability assessment of hydro-processed renewable jet fuel from algae from market-entry year 2020: Use in passenger aircrafts. In: 16th AIAA Aviation Technology, Integration, and Operations Conference, Reston, Virginia, USA; 2016.

[8] IATA. Climate Change. Retrieved from https://www.iata.org/policy/ environment/Pages/climate-change.aspx; 2 July, 2019.

[9] Ashcraft SW, Padron AS, Pascioni KA, et al. Review of propulsion technologies for $\mathrm{n}+3$ subsonic vehicle concepts. 2011. Retrieved from https://ntrs. nasa.gov/archive/nasa/casi.ntrs.nasa.gov/20110022435.pdf; 2 July, 2019.

[10] Greitzer EM, Bonnefoy PA, De la Rosa Blanco E, et al. N+ 3 Aircraft Concept Designs and Trade Studies Final Report, Nasa cr-2010-216794/vol2, NASA Glenn Res. Center, Cleveland, Ohio, vol. 44135, 2010.

[11] Liebeck RH. Design of the blended wing body subsonic transport. Journal of Aircraft 2004; 41: 10-25.

[12] Benzakein MJ. What does the future bring? A look at technologies for commercial aircraft in the years 2035-2050. Propulsion and Power Research 2014; 3: 165174.

[13] Emerson BL, Jagtap S, Lieuwen TC. Stability analysis of reacting wakes: flow and density asymmetry effects. In: 53rd AIAA Aerospace Sciences Meeting. Reston, Virginia, USA; 2015.

[14] Emerson B, Jagtap S, Quinlan JM, et al. Spatio-temporal linear stability analysis of stratified planar wakes: Velocity and density asymmetry effects. Physics of Fluids 2016; 28: 045101.

[15] Daggett DL, Hendricks RC, Walther R, et al. Alternate fuels for use in commercial aircraft. In: 18th International Society for Air Breathing Engines Beijing, China; September 2-7, 2007.

[16] Jagtap SS. Comparative assessment of manufacturing setups for blended sugarto-aviation fuel production from non-food feedstocks for green aviation. In: AIAA 
[17] Jagtap SS. Evaluation of blended Fischer-Tropsch jet fuel feedstocks for minimising human and environmental health impacts of aviation. In: AIAA Propulsion and Energy 2019 Forum, Indianapolis, USA; August 2019.

[18] Jagtap SS. Assessment of feedstocks for blended alcohol-to-jet fuel manufacturing from standalone and distributed scheme for sustainable aviation. In: AIAA Propulsion and Energy 2019 Forum, Indianapolis, USA; August 2019.

[19] Haq Z, Kostova B. Biofuels in defense and aviation. 2017. Retrieved from https://www.energy.gov/sites/prod/files/2017/03/f34/day_3_plenary_haq_aviatio n_overview.pdf; 2 July, 2019.

[20] Fonseca E. Heat recovery system for a gas turbine engine. US20140190162A1, USA, 2012

[21] Perullo CA, Mavris DN, Fonseca E. An integrated assessment of an organic Rankine cycle concept for use in onboard aircraft power generation. InASME Turbo Expo 2013: Turbine Technical Conference and Exposition 2013 Jun 3. American Society of Mechanical Engineers Digital Collection.

[22] Jagtap SS. Heat recuperation system for the family of shaft powered aircraft gas turbine engines. Retrieved from https://patents.google.com/patent/ US10358976B2/en; 27 September, 2019

[23] Jagtap SS. Heat recuperation system for the family of shaft powered aircraft gas turbine engines. Retrieved from https://patentscope.wipo.int/search/en/detail. jsf?docId=WO2016067303; 2 July, 2019.

[24] Jagtap SS. An apparatus for exchanging heat with flow in an annulus. Journal of Engineering Science and Technology Review 2017; 10: 173-176.

[25] Pornet C, Isikveren AT. Conceptual design of hybrid-electric transport aircraft. Progress in Aerospace Sciences 2015; 79: 114-135.

[26] Friedrich C, Robertson PA. Hybrid-electric propulsion for aircraft. Journal of Aircraft 2015; 52: 176-189.

[27] Voskuijl M, van Bogaert J, Rao AG. Analysis and design of hybrid electric regional turboprop aircraft. CEAS Aeronautical Journal 2018; 9: 15-25.

[28] Schäfer AW, Barrett SRH, Doyme K, et al. Technological, economic and environmental prospects of all-electric aircraft. Nature Energy 2018; 4: 160.

[29] Burge-Hughes-Walsh. Training and consultancy in systems design and process improvement. Retrieved from https://www.burgehugheswalsh.co.uk/systemsengineering/benefits.aspx; 2 July, 2019.

[30] Hathaway M, Del Rosario R, Madavan NK. NASA fixed wing project propulsion research and technology development activities to reduce thrust specific energy consumption. In: 49th AIAA/ASME/SAE/ASEE Joint Propulsion Conference, California, USA; 2013.

[31] Graham WR, Hall CA, Vera Morales M. The potential of future aircraft technology for noise and pollutant emissions reduction. Transport Policy 2014; 34: $36-51$.

[32] Chambers JT, Yutko BM, Singh R, et al. Structural optimization study of the D8 double-bubble composite fuselage. In: 58th AIAA/ASCE/AHS/ASC Structures, Structural Dynamics, and Materials Conference, Texas, USA, pp. 508; 2017.

[33] Armstrong MJ, Ross CAH, Blackwelder MJ, et al. Trade studies for NASA N3$\mathrm{X}$ turboelectric distributed propulsion system electrical power system architecture. SAE International Journal of Aerospace 2012; 5: 325-336.

[34] Bradley MK, Droney CK. Subsonic ultra green aircraft research: phase I final 
report. Report, National Aeronautics and Space Administration, USA, 2011.

[35] Bruner S, Baber S, Harris C, et al. NASA N+ 3 subsonic fixed wing silent efficient low-emissions commercial transport (SELECT) vehicle study. Revision A. Ohio: National Aeronautics and Space Administration; 2010.

[36] Kim HD, Brown G V, Felder JL. Distributed turboelectric propulsion for hybrid wing body aircraft. In: 2008 Internation Powered Lift Conference, London, UK; 2008.

[37] Felder J, Kim H, Brown G. Turboelectric distributed propulsion engine cycle analysis for hybrid-wing-body aircraft. In: 47th AIAA aerospace sciences meeting including the new horizons forum and aerospace exposition. 2009, p. 1132.

[38] Schrage DP. Technology for rotorcraft affordability through integrated product/process development (IPPD). In: American Helicopter Society 55th AnnualForum, Montreal, Canada, 25-29 May, 1999.

[39] Press DA. Systems engineering fundamentals. Defense Systems Management College Press, Fort Belvoir, Virginia. Jan 2001.

[40] Shafer SM, Smith HJ, Linder JC. The power of business models. Business Horizons 2005; 48: 199-207.

[41] Ahmed S, Hassan M. Survey and case investigations on application of quality management tools and techniques in SMIs. International Journal of Quality \& Reliability Management 2003; 20: 795-826.

[42] Karsak EE, Sozer S, Alptekin SE. Product planning in quality function deployment using a combined analytic network process and goal programming approach. Computers \& Industrial Engineering 2003; 44: 171-190.

[43] Anjard RP. Management and planning tools. Training for Quality 1995; 3: 34-37.

[44] Rajamanickam R, Park S, Jayaraman S. A structured methodology for the design and development of textile structures in a concurrent engineering framework. Journal of the Textile Institute 1998; 89: 44-62.

[45] Akao Y. Quality Function Deployment. Integrating Customer Requirements into Product Design. 1st ed. Taylor \& Francis; 2004.

[46] Hauser JR, Clausing D. The house of quality. Harvard Business Review 1988; 6373.

[47] Tapke J, Muller A, Johnson G, Sieck J. House of quality. Steps in understanding the house of quality. Retrieved from https://vardeman.public.iastate.edu/ IE361/f01mini/johnson.pdf; 19 December, 2019.

[48] Chan L-K, Wu M-L. A systematic approach to quality function deployment with a full illustrative example. Omega 2005; 33: 119-139.

[49] Hauser JR. How Puritan-Bennett used the house of quality. Sloan Management Review 1993; 34: 61-70.

[50] Bode J, Fung RYK. Cost engineering with quality function deployment. Computers \& Industrial Engineering 1998; 35: 587-590.

[51] Besterfield DH, Besterfield-Michna C, Besterfield-Sacre M, Besterfield GH, Urdhwareshe H. Total Quality Management: For Anna University. Pearson Education India; 2011.

[52] Hultgren LS. CORE NOISE: Implications of emerging N+3 designs and acoustic technology needs. Retrieved from https://ntrs.nasa.gov/archive/nasa/casi.ntrs. nasa.gov/20110011393.pdf; 2 July, 2019.

[53] Rogers MM. Technical challenges to reducing subsonic transport drag. 2012. Retrieved from https://ntrs.nasa.gov/archive/nasa/casi.ntrs.nasa.gov/ 20120006660.pdf; 2 July, 2019. 
[54] Kohavi R, Deng A, Frasca B, et al. Trustworthy online controlled experiments: Five puzzling outcomes explained. In: Proceedings of the 18th ACM SIGKDD international conference on Knowledge discovery and data mining. ACM, 2012, pp. 786-794.

[55] Ruder JA, Sobek DK. Experiment on a system-level design tool. Journal of Engineering Design. 2007 Aug 1;18(4):327-42.

[56] Ayag Z. An integrated approach to evaluating conceptual design alternatives in a new product development environment. International Journal of Production Research 2005; 43: 687-713.

[57] Takai S, Ishii K. Modifying Pugh's design concept evaluation methods. In: ASME 2004 International Design Engineering Technical Conferences and Computers and Information in Engineering Conference. American Society of Mechanical Engineers, pp. 415-424; 2004.

[58] Jato-Espino D, Castillo-Lopez E, Rodriguez-Hernandez J, Canteras-Jordana JC. A review of application of multi-criteria decision making methods in construction. Automation in Construction 2014; 45: 151-162.

[59] Laroche M, Mukherjee A, Nath P. An empirical assessment of comparative approaches to service quality measurement. Journal of Services Marketing 2005; 19(3): 174-184.

[60] Opricovic S, Tzeng G-H. Compromise solution by MCDM methods: A comparative analysis of VIKOR and TOPSIS. European Journal of Operational Research 2004; 156: 445-455. 